by Shuhai Xiao', Guy M. Narbonne ${ }^{2}$, Chuanming Zhou ${ }^{3}$, Marc Laflamme, $^{4}$

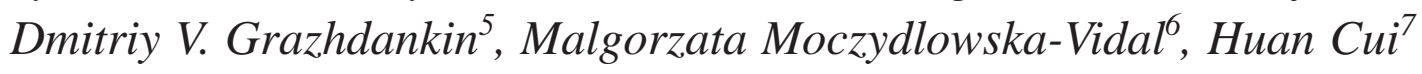

\title{
Towards an Ediacaran Time Scale: Problems, Protocols, and Prospects
}

\author{
${ }^{1}$ Department of Geosciences, Virginia Tech, Blacksburg, Virginia 24061, USA.E-mail: xiao@vt.edu \\ 2 Department of Geological Sciences and Geological Engineering, Queen's University, Kingston, Ontario K7L 3N6, Canada \\ ${ }^{3}$ Key Laboratory of Economic Stratigraphy and Palaeogeography, Nanjing Institute of Geology and Palaeontology, \\ Chinese Academy of Sciences, Nanjing 210008, China \\ ${ }^{4}$ University of Toronto Mississauga, 3359 Mississauga Road, Mississauga, Ontario L5L 1C6, Canada \\ 5 Trofimuk Institute of Petroleum Geology and Geophysics, Siberian Branch of the Russian Academy of Sciences, \\ prospekt Akademika Koptyuga 3, Novosibirsk 630090, Russia \\ ${ }^{6}$ Department of Earth Sciences, Uppsala University, Villavägen 16, SE 75236 Uppsala, Sweden \\ ${ }^{7}$ Department of Geoscience and NASA Astrobiology Institute, University of Wisconsin, Madison, Wisconsin 53706, USA
}

(Received: 23/12/2015; Accepted: 4/9/2016)

DOI:10.18814/epiiugs/2016/v39i4/103886

The Ediacaran Period follows the Cryogenian Period in the wake of a snowball Earth glaciation and precedes the Cambrian Period with its rising tide of animal radiation. It is also the longest among all stratigraphically defined geological periods, lasting 94 million years (635-541 Ma). Hence, a good Ediacaran time scale is essential, not only to elucidate geological time, but also to provide a temporal context for extreme climatic events and transformative evolutionary transitions. Ediacaran fossils are known from many sections and boreholes around the world, permitting ready age recognition and stratigraphic correlation of Ediacaran strata. However, the Ediacaran fossil record is colored by taphonomic biases that variously affect the preservation of the soft-bodied organisms that dominated Ediacaran marine ecosystems, and the Phanerozoic approach of defining stratigraphic boundaries using the first appearance datum (FAD) of widely distributed, rapidly evolving, easily recognizable, and readily preservable species would have limited success in the Ediacaran System. The subdivision of the Ediacaran System must therefore be founded on a holistic approach integrating biostratigraphic, chemostratigraphic, and geochronometric data for correlation. Series-level subdivision of the Ediacaran System is a challenging task, and alternative models subdividing the Ediacaran System into two or three series can be recognized. Resolving these alternatives critically depends on obtaining further data to constrain the age, duration, and global extent of the Shuram negative $\delta^{13} C$ excursion, to calibrate and correlate Ediacaran acanthomorph biozones, and to determine the temporal relationship among the Shuram excursion, the Gaskiers glaciation, and Ediacaran acanthomorph biozones. Stage-level subdivisions at the bottom and top of the Ediacaran System, however, are realistic goals in the near future, and we propose that the subdivision of the Ediacaran System should initially aim at the second Ediacaran stage (SES) and the terminal Ediacaran stage (TES) where stratigraphic information is relatively rich and consensus for stratigraphic correlation is emerging. Potential stratigraphic markers for the definition of the SES include the post-glacial radiation of eukaryotes as represented by the first appearance of acanthomorph acritarchs, the termination of the cap carbonate series, or the end of the negative $\delta^{13} C$ excursion $(E N 1=$ Ediacaran negative excursion 1) associated with the cap carbonate. Terminal Ediacaran strata are well dated and host several taxa of skeletal and tubular fossils that postdate the Shuram negative $\delta^{13} \mathrm{C}$ excursion (or its probable equivalent, EN3 = Ediacaran negative excursion 3) where their stratigraphic relationship can be determined; these biostratigraphic markers may be used to define the TES in a Phanerozoic fashion. Additional Ediacaran stages between the SES and TES can be envisioned. Through collaborative efforts in the Ediacaran 
community, we hope that the first Precambrian stage will be established in the near future to facilitate a better understanding of the geological aftermath of snowball Earth, the redox history of global oceans, the early evolution of multicellular life, and the evolutionary fuse of the Cambrian explosion.

\section{Introduction}

The Ediacaran System was ratified in 2004 (Knoll et al., 2004; Knoll et al., 2006), with its basal boundary defined by a horizon near the base of the Nuccaleena Formation overlying the Cryogenian diamictite of the Elatina Formation at the Enorama Creek section in South Australia (Fig. 1). In 2004, the Subcommission on Ediacaran Stratigraphy (later renamed the Subcommission on Neoproterozoic Stratigraphy) was established to facilitate the correlation and subdivision of the Cryogenian and Ediacaran periods. The Subcommission on Neoproterozoic Stratigraphy conducted a survey in 2009 to gauge the community's opinion on how to proceed with the subdivision and correlation of the Ediacaran System. Responses came from 20 voting members and 12 corresponding members. The results are summarized in Fig. 2. Briefly, the survey suggested that the Ediacaran System should be first divided into two series, with the lower series characterized by acanthomorphic acritarchs and the upper series by Ediacara-type macrofossils. It was further suggested that, ideally, the base of the upper Ediacaran series should be placed within an outcrop section that has good radiometric age constraints and has the potential for carbon isotope chemostratigraphic and acanthomorphic acritarch biostratigraphic correlation. At that time, it was felt that (1) the subdivision of the Ediacaran System should start with the establishment of two series before the definition of stages, (2) the most useful correlation tools included chemostratigraphy such as $\delta^{13} \mathrm{C}$ and ${ }^{87} \mathrm{Sr} /{ }^{86} \mathrm{Sr}$ excursions, acanthomorphic acritarchs, and Ediacara-type macrofossils, and (3) good GSSPs should be fossiliferous, geochronometrically dated, and have mixed lithologies and the potential for chemostratigraphic and biostratigraphic correlations.

In 2012, the Subcommission on Neoproterozoic Stratigraphy was split into the Subcommission on Cryogenian Stratigraphy and the Subcommission on Ediacaran Stratigraphy. The stated goal of the

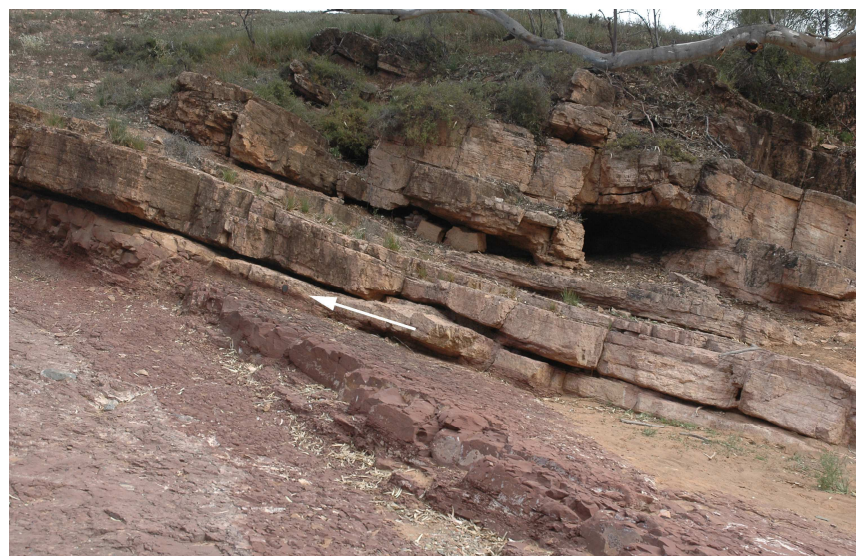

Figure 1. Ediacaran GSSP (arrow) at Enorama Creek, South Australia.

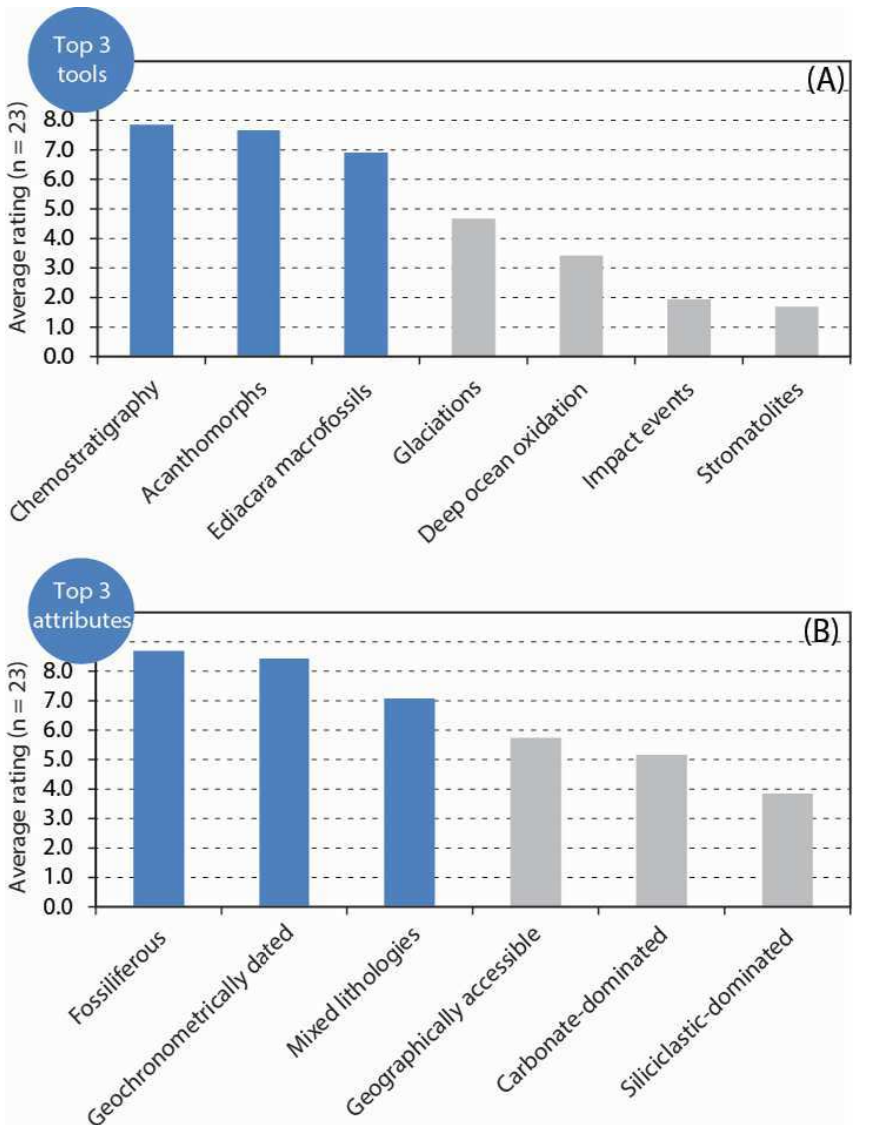

Figure 2. Responses to the 2009 survey questions: (A) to rate the practicality of criteria for Ediacaran stratigraphic correlations, using a scale of 1 (least practical criterion) to 10 (most practical criterion); and (B) to evaluate the importance of factors that need to be considered in the process of selecting GSSPs for the subdivision of the Ediacaran System, using a scale of 1 (least important) to 10 (most important).

Subcommission on Ediacaran Stratigraphy is to facilitate international communication and scientific cooperation in Ediacaran stratigraphy, with the ultimate goal to define, by means of GSSPs, a hierarchy of chronostratigraphic units that provide the framework for global correlation. In the past decade, the Subcommission on Ediacaran Stratigraphy and its predecessor organized and sponsored several field workshops to examine potential criteria for Ediacaran subdivision and correlation (Moczydlowska-Vidal et al., 2008; Kumar and Sharma, 2010; Xiao et al., 2011; Gehling and Droser, 2012; Gehling et al., 2012; Kumar and Sharma, 2012; Narbonne et al., 2012a; Kaufman et al., 2014; Pandey and Dimri, 2014; Singh and Ansari, 2014; Xiao and Sharma, 2014; Xiao et al., 2014b). As part of the efforts toward the establishment of intra-Ediacaran GSSPs, we have encouraged-at various scientific meetings and workshops, notably the 2014 Ediacaran Workshop in Wuhan, China, and the STRATI 2015 meeting in Graz, Austria-community-wide discussions about the subdivision and correlation of Ediacaran strata. The purpose of this paper is to summarize the key issues emerging from these discussions and to offer a view on strategies to move forward.

\section{Problems and Challenges}

The biostratigraphic and chemostratigraphic basis for the 
subdivision and correlation of Ediacaran strata has been summarized in Narbonne et al. (2012b), who acknowledged the unique challenges in Ediacaran biostratigraphy due to the dearth of skeletal fossils but also recognized potential opportunities of using climatic and chemostratigrpahic events (e.g., Gaskiers glaciation and Shuram $\delta^{13} \mathrm{C}$ excursion) as tools to correlate Ediacaran strata. The predominance of non-skeletal fossils in the Ediacaran System means that the documented stratigraphic range of key Ediacaran fossils is more prone to taphonomic limitations than their Phanerozoic counterparts. Hence, the index fossil approach using the first appearance datum (FAD) to define and correlate stratigraphic boundaries-so successfully employed in the establishment of Phanerozoic GSSPs-must be carefully scrutinized and tested against other independent approaches. Because of this, the subdivision and correlation of the Ediacaran System needs to emphasize the characteristic stratigraphic content within the subdivision, as much as the stratigraphic marker at the subdivision boundary. Similarly, because of taphonomic biases in the preservation of soft-bodied organisms, correlation of Ediacaran strata is forced to be routinely based on non-biostratigraphic markers such as $\delta^{13} \mathrm{C}$ chemostratigraphic excursions. However, correlation based on non-directional physical and chemical changes such as glaciation events and chemostratigraphic excursions requires independent calibrations using radiometric dates and biostratigraphic data. Recognizing these challenges, Narbonne et al. (2012) saw the benefits of examining alternative models to divide the Ediacaran System into two or three series (Fig. 3), although the initial survey of the Subcommission on Neoproterozoic Stratigraphy in 2009 recommended a two-series approach.

In the two-series model, the Ediacaran System would include a lower series characterized by acanthomorphic acritarchs and an upper series by Ediacara-type macrofossils. The two series would be separated from each other by the Gaskiers glaciation that is hypothetically correlated with a negative $\delta^{13} \mathrm{C}$ excursion named EN2 or Ediacaran negative excursion 2 (Zhou and Xiao, 2007). The excursion EN2 occurs in the middle Doushantuo Formation in South China and is later recognized as BAINCE, or the Baiguoyuan negative carbon isotope excursion (Zhu et al., 2013b). The other widely recognized negative $\delta^{13} \mathrm{C}$ excursions in the Doushantuo Formation include EN1 (Ediacaran negative excursion 1) in the basal Doushantuo cap dolostone and EN3 (Ediacaran negative excursion 3) in the uppermost Doushantuo Formation (Jiang et al., 2007; Zhou and Xiao, 2007). In the two-series model, the most prominent negative $\delta^{13} \mathrm{C}$ excursion in the Doushantuo Formation - namely EN3, which is widely regarded as a correlative of the Shuram negative $\delta^{13} \mathrm{C}$ excursion (Grotzinger et al., 2011) — would be in the upper series and would be younger that the Gaskiers glaciation.

In the three-series model, the Ediacaran System would be divided into (1) a lower series characterized by the initial post-glacial radiation of eukaryotes as represented by the early acanthomorph assemblage dominated by Tianzhushania spinosa (Fig. 4A) that primarily occurs in the lower Doushantuo Formation of South China (McFadden et al., 2009; Liu et al., 2013b; Xiao et al., 2014a), (2) a middle series characterized by more diverse acanthomorph assemblages (Fig. 4BC) as represented by acritarch assemblages in Australia, Siberia, and the East European Platform, as well as the upper Doushantuo Formation in South China (Moczydlowska et al., 1993; Grey, 2005; Willman et al., 2006; Willman, 2007; Willman and Moczydlowska, 2008; Vorob'eva et al., 2009; Sergeev et al., 2011; Willman and Moczydlowska, 2011; Moczydlowska and Nagovitsin, 2012; Xiao et al., 2012; Liu et al., 2014d; Shukla and Tiwari, 2014; Joshi and Tiwari, 2016), and (3) an upper series branded by Ediacara-type macrofossils (Fig. 4D-F) and tubular and ribbon-shaped fossils (Fig. 4G-K) (Grazhdankin, 2014; Narbonne et al., 2014). In this model, it is implied that the Gaskiers glaciation is correlated with EN3 rather than EN2. As such, the lower and middle series would be separated by EN2, and the middle and upper series by Shuram/EN3 and by the Gaskiers glaciation.

As is clear from the two alternative models presented in Narbonne et al. (2012b), one of the most difficult tasks in Ediacaran stratigraphy is the correlation of biostratigraphic, chemostratigraphic, and climatic markers, and the difficulty stems from the fact that these markers tend to be preserved in different lithofacies and in different basins. For example, it is uncertain whether the negative $\delta^{13} \mathrm{C}$ excursion associated with the Gaskiers diamictite in Newfoundland (Myrow and Kaufman, 1999) is of global extent, and how it is correlated with the multiple negative $\delta^{13} \mathrm{C}$ excursions present in carbonate-dominated successions (e.g., in South China where no Gaskiers-age glacial diamictite was deposited). It is also a matter of debate whether Ediacaran negative $\delta^{13} \mathrm{C}$ excursions-such as EN1 in the cap carbonate, EN2 in the middle Doushantuo Formation, and Shuram/ EN3 in the Shuram Formation, upper Doushantuo Formation, Wonoka Formation, and other potentially correlative strata-represent disturbances of the global carbon cycle and thus have chemostratigraphic significance. If they do, then the temporal relationships between these negative $\delta^{13} \mathrm{C}$ excursions and climatic and evolutionary events (e.g., the Gaskiers glaciation, DoushantuoPertatataka-type acanthomorphs, and Ediacara-type macrofossils) need to be determined. Below, we offer a brief review of paleoclimatic, biostratigraphic, chemostratigraphic, and geochronometric data of the Ediacaran Period in order to illustrate some of these correlation problems.

\section{Paleoclimatic data}

Glacial diamictites of the Gaskiers Formation in Newfoundland are constrained between 583.7 Ma and 582.1 Ma (Fig. 5) (Hoffman and Li, 2009; Schmitz, 2012). Possible equivalents of the Gaskiers diamictite include the Squantum Tillite in the Boston Basin (Thompson and Bowring, 2000), the Croles Hill diamictite in Tasmania (Calver et al., 2004), the Moelv diamictite in southern Norway (Bingen et al., 2005), the Hankalchough diamictite in Tarim (Xiao et al., 2004), and other diamictites in Western Australia, Baltica, Cadomia, Laurentia, and North China (Hoffman and Li, 2009; Li et al., 2013). However, Ediacaran successions in these areas are typically dominated by siliciclastics (Hoffman and Li, 2009), which render a spotty $\delta^{13} \mathrm{C}$ chemostratigraphic record. Thus, direct correlation of the Gaskiers glaciation with $\delta^{13} \mathrm{C}$ chemostratigraphic excursions is not straightforward, and indirect correlation must be dependent on acanthomorph biostratigraphy as a bridge. In this regard, the Biskopås Formation in southern Norway, which is older than the Moelv Formation and contains Doushantuo-Pertatataka-type acanthomorphs (Vidal, 1990; Adamson and Butterfield, 2014), would provide insights into the temporal relationship between biostratigraphic zonations and climatic events. Biostratigraphic data from the Biskopås Formation suggest that at least some members of Doushantuo-Pertatataka-type acanthomorphs appeared before the Gaskiers glaciation. Traditionally, Doushantuo-Pertatataka-type acanthomorphs are believed to be restricted to the lower Ediacaran System, predating the Gaskiers 

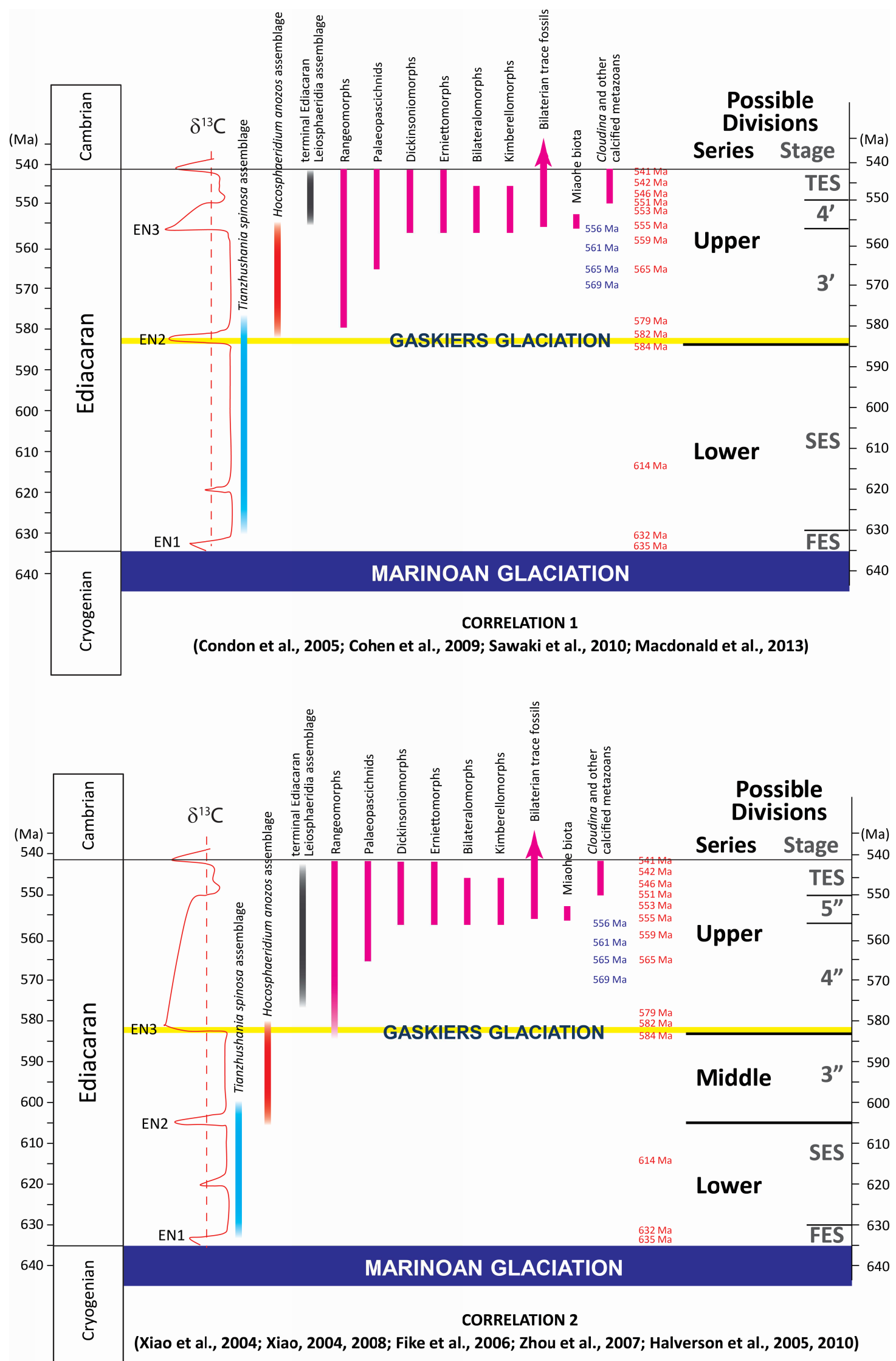

Figure 3. Two models for Ediacaran subdivision and correlation, modified from Narbonne et al. (2012b). The key difference between these two models relates to how the Shuram excursion is correlated with the Gaskiers glaciation. Radiometric ages shown in red are from Schmitz (2012) and those shown in blue are from Noble et al. (2015). For clarity, all radiometric ages are rounded to the nearest integers. FES: first Ediacaran stage; SES: second Ediacaran stage; TES: terminal Ediacaran stage. 

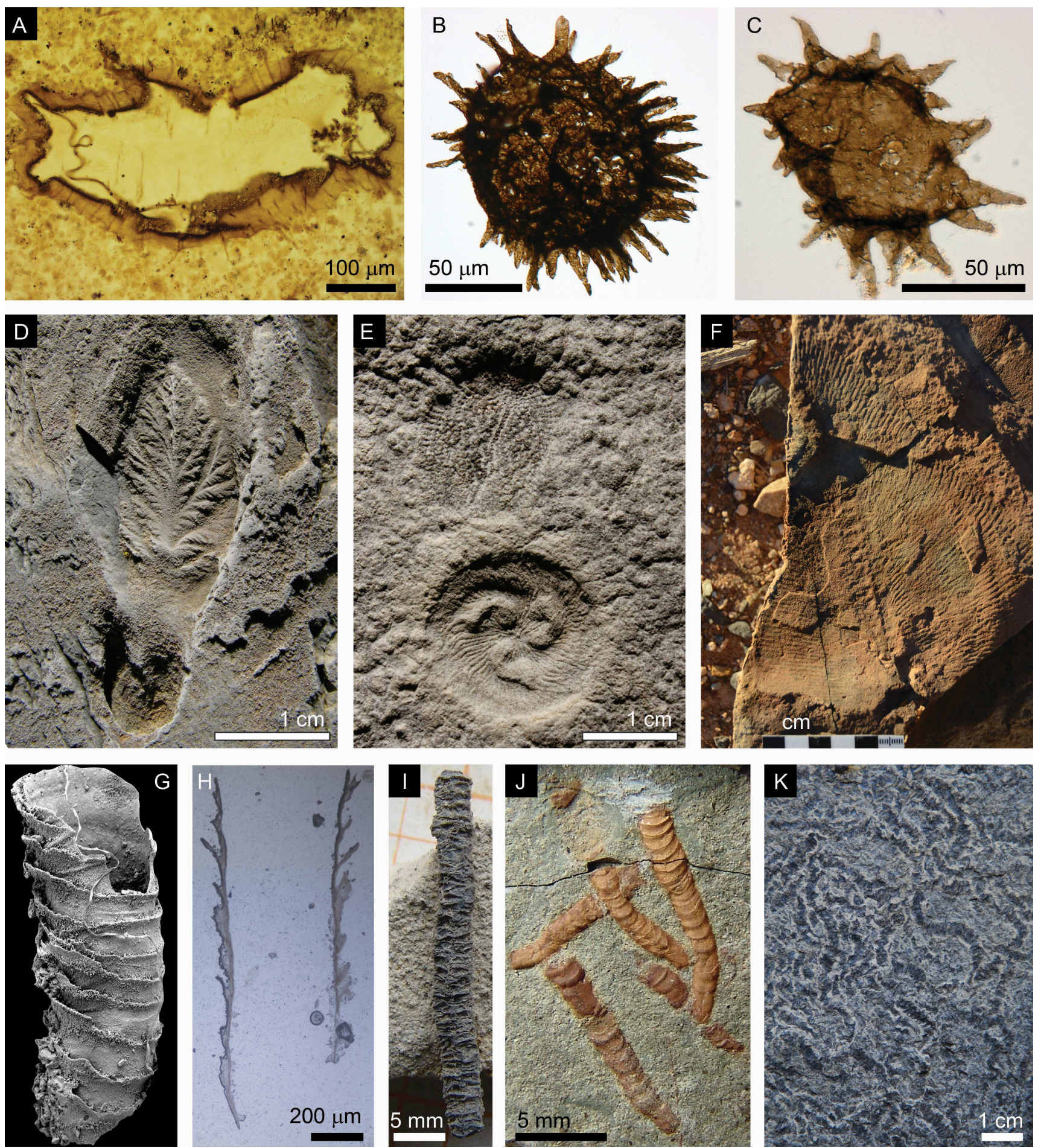

Figure 4. Representative Ediacaran fossils, including acanthomorphs from the early-middle Ediacaran (A-C), Ediacara-type macrofossils from the middle-upper Ediacaran (D-E), and Ediacara-type macrofossil (F) and tubular or ribbon-shaped fossils (G-K) from the terminal Ediacaran. (A) Tianzhushania spinosa from lower Member II of the Doushantuo Formation in the Yangtze Gorges area, South China. WD-71-5 (156×34.5), $7.35 \mathrm{~m}$ above top of cap dolostone (Zhou et al., 2007). (B) Tanarium digitiformum (PN8/4-17/7-2) and (C) Tanarium tuberosum (PN8/4-17/6-3) from the Ura Formation of eastern Siberia (Moczydlowska and Nagovitsin, 2012). (D) Rangeomorph Beothukis mistakensis (NFM F-758) in the Avalon assemblage, Trepassey Formation, Spaniard's Bay, Newfoundland (Narbonne et al., 2009). (E) Tribrachidium heraldicum (lower) and Solza margarita (upper) in the White Sea assemblage, Yorga Formation, Zimnie Gory, White Sea, Russia. (F) Swartpuntia germsi in the Nama assemblage, Spitzkopf Member, Urusis Formation, Nama Group, Farm Swartpunt, southern Namibia. (G-H) Phosphatized Cloudina riemkeae (LJG-174048), (I) Sinotubulites baimatuoensis (courtesy of Zhe Chen), and (J) Conotubus hemiannulatus (20040128, courtesy of Yaoping Cai), Dengying Formation, southern Shaanxi Province, South China. (H) is longitudinal cross section of (G), showing nested funnels (Hua et al., 2005). (K) Shaanxilithes ningqiangensis, Taozichong Formation, Guizhou Province, South China (Hua et al., 2004). 
glaciation and the Shuram excursion (Zhou et al., 2007). However, elements of Doushantuo-Pertatataka-type acanthomorphs have recently been reported from presumably terminal Ediacaran strata (Golubkova et al., 2015); these occurrences need to be critically evaluated in order to test the two alternative models of correlation (Fig. 3).

\section{Biostratigraphic data}

Doushantuo-Pertatataka-type acanthomorphs have been recovered from a number of Ediacaran successions in South China (Liu et al., 2014d; Xiao et al., 2014a), Australia (Grey, 2005; Willman et al., 2006; Willman, 2007; Willman and Moczydlowska, 2008, 2011), Siberia (Moczydlowska et al., 1993; Sergeev et al., 2011; Moczydlowska and Nagovitsin, 2012), India (Shukla and Tiwari, 2014; Joshi and Tiwari, 2016), Svalbard (Knoll, 1992), and the East European Platform (Vorob'eva et al., 2009; Golubkova et al., 2015). Doushantuo-Pertatataka-type acanthomorphs as a whole seem to be restricted to the lower Ediacaran System, below the Gaskiers-age Moelv diamictite in southern Norway and below negative $\delta^{13} \mathrm{C}$ excursions in South China, South Australia, and Siberia that are interpreted as equivalent to the Shuram excursion (Fig. 5). However, as mentioned above, recent reports of elements of DoushantuoPertatataka-type acanthomorphs in terminal Ediacaran rocks (Golubkova et al., 2015) need to be assessed critically.

Acanthomorph biozonation has been applied with variable success in different basins. Four acanthomorph assemblage zones have been recognized in Australia (Grey, 2005), but their application in biostratigraphic correlation outside Australia has met with limited success. For example, although many of the Australian species have been recognized in Ediacaran successions in South China, Siberia, and the East European Platform, a succession of the four Australian assemblage zones have not been documented in these areas. In South China, two acanthomorph assemblage zones are recognized insteadthe Tianzhushania spinosa assemblage zone in the lower Doushantuo Formation and the Hocosphaeridium anozos assemblage zone in the middle-upper Doushantuo Formation (Liu et al., 2014d; Xiao et al., 2014a). The Tianzhushania spinosa assemblage zone begins shortly after the basal Ediacaran cap carbonate (McFadden et al., 2009), in close proximity to the $632.48 \pm 1.02 \mathrm{Ma}$ age. It has been proposed that the Tianzhushania spinosa assemblage zone may have been missing - for taphonomic, paleoecological, or paleobiogeographic reasons-from early Ediacaran successions in most other continents, and that the Hocosphaeridium anozos assemblage zone may be correlated with the four acanthomorph assemblage zones recognized in Australia (Liu et al., 2014d; Xiao et al., 2014a), but this correlation needs to be further investigated.

Ediacaran acanthomorph biostratigraphy is complicated by taphonomic vagaries in the preservation, environmental control on the distribution, and inconsistencies in the taxonomy of Ediacaran acanthomorphs. Acanthomorphs preserved in chert nodules and phosphorites, in particular, are subject to taphonomic biases associated with authigenic mineralization (Zhou et al., 2007; Muscente et al., 2015). This is best illustrated by the significant variation in acanthomorph abundance and diversity among different Doushantuo sections in the Yangtze Gorges area (Zhou et al., 2007; McFadden et al., 2009; Muscente et al., 2015). Taphonomic degradation also introduces morphological alterations that could compromise taxonomic identification (Grey and Willman, 2009). In addition, preliminary data show that the distribution of Ediacaran acanthomorphs may be facies dependent, and paleoenvironments may be a factor that controls the presence or absence of acanthomorph taxa (Zhou et al., 2007; Nagovitsin and Kochnev, 2015). Furthermore, acanthomorphs preserved in cherts, phosphorites, and shales are analyzed using different techniques (e.g., thin sectioning, acetic acid maceration, and hydrofluoric acid maceration, respectively). These different methods can also introduce inconsistencies in acanthomorph taxonomy (Xiao et al., 2014a). Due to these taphonomic and methodological factors, it is possible that the taxonomic diversity of Ediacaran acanthomorphs has been greatly inflated and major efforts to standardize acanthomorph taxonomy are needed in order to enable biostratigraphic subdivision and correlation.

Certain taxa or assemblages of Ediacara-type macrofossils may also have biostratigraphic significance. Ediacara-type fossils consist of macroscopic, soft-bodied, morphologically complex, and phylogenetically diverse eukaryotes including animals (Narbonne, 2005; Xiao and Laflamme, 2009; Laflamme et al., 2013; Liu et al., 2014a). These organisms have a global distribution with species reported from every continent except Antarctica. Three assemblages of Ediacara-type macrofossils have been recognized, including the Avalon, White Sea, and Nama assemblages (Waggoner, 1999, 2003; Shen et al., 2008). Although paleoecology and paleoenvironments may have exerted some control on the spatial and temporal distribution of these three assemblages (Grazhdankin, 2004; Gehling and Droser, 2013), evolutionary succession seems to be a major factor (Grazhdankin, 2014; Grazhdankin and Maslov, 2015). As such, these three assemblages may have biostratigraphic significance.

However, the greatest difficulty in using Ediacara macrofossils sensu stricto (i.e., soft-bodied Ediacara macrofossils excluding skeletal fossils such as Cloudina, Namacalathus, and Sinotubulites) for biostratigraphic purposes lies in their mode of preservation. The overwhelming majority of Ediacara-type macrofossils are preserved as impressions on the tops and bottoms of fine- to medium-grained sandstone beds, and in rare instances as casts/molds or carbonaceous compressions in carbonates or mudstones (Sun, 1986; Grazhdankin et al., 2008; Zhu et al., 2008; Xiao et al., 2013; Chen et al., 2014). Their preservation requires a series of exceptional circumstances, the origins of which are still not fully understood (Gehling, 1999; Narbonne, 2005; Laflamme et al., 2011; Darroch et al., 2012; Kenchington and Wilby, 2014). Unique taphonomic settings linked to the vast expanses of microbial mats in Ediacaran oceans may have played a constructive role to improve the preservational fidelity of Ediacara macrofossils (Callow and Brasier, 2009), but how they may have biased the preservation of soft-bodied Ediacara-type macrofossils is unknown. These taphonomic biases must be analyzed and considered when using the FAD of Ediacara-type macrofossils for biostratigraphic correlation. In addition, because the majority of Ediacara-type macrofossils are preserved in siliciclastic successions, which are inappropriate for chemostratigraphic analysis, their correlation with $\delta^{13} \mathrm{C}$ excursions is not an easy task. In this regard, the search of Ediacara-type macrofossils in carbonate successions (Sun, 1986; Grazhdankin et al., 2008; Chen et al., 2014) and $\delta^{13} \mathrm{C}$ chemostratigraphic analysis of carbonate interbeds in predominantly siliciclastic successions that bear Ediacara-type macrofossils (Macdonald et al., 2013; Wood et al., 2015) would alleviate some of the problems hampering the correlation between Ediacara-type fossils and $\delta^{13} \mathrm{C}$ excursions.

Several macrofossils from terminal Ediacaran strata stand out for 

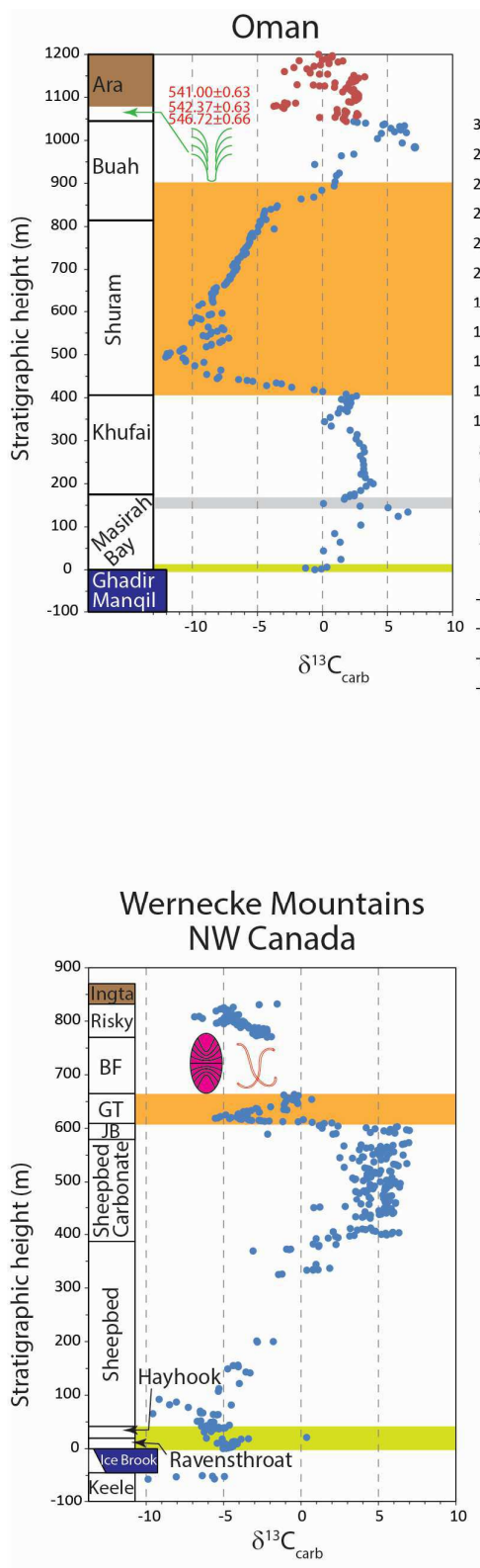

$$
\text { Acanthomorphs }
$$

Acanthomorphs
(Tianzhushania spinosa assemblage)

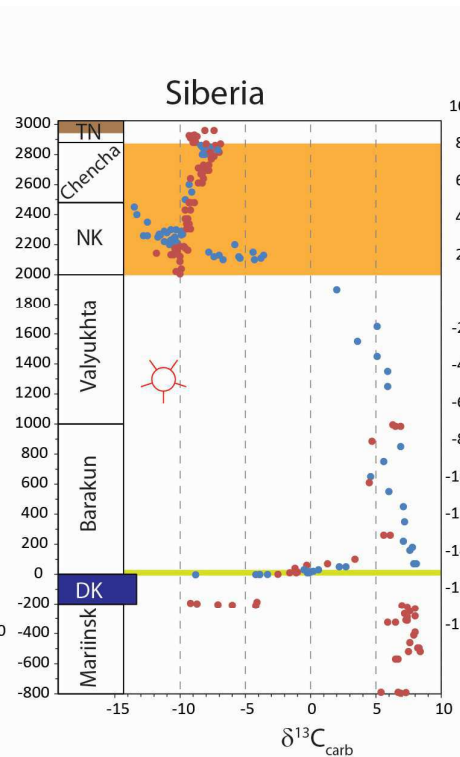

SE Mackenzie Mountains NW Canada

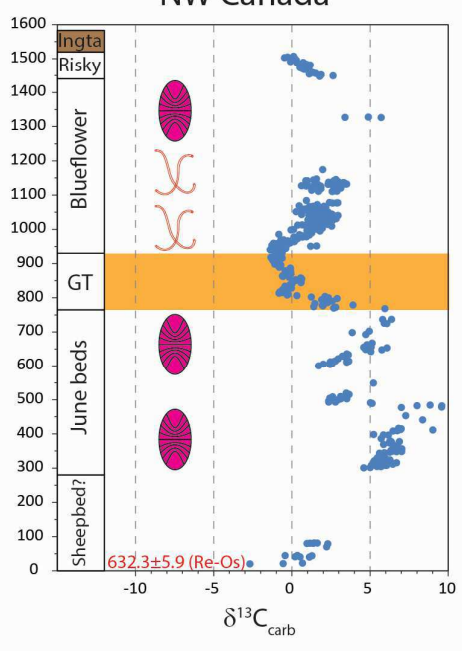

South Australia

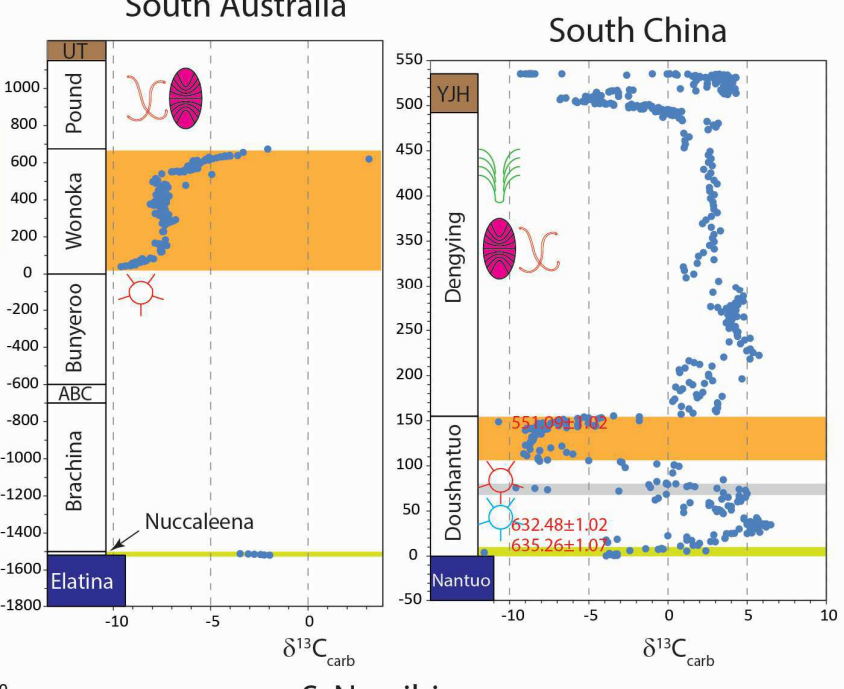

S. Namibia

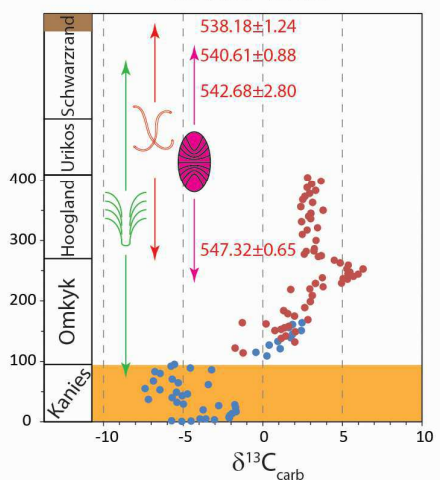

Newfoundland

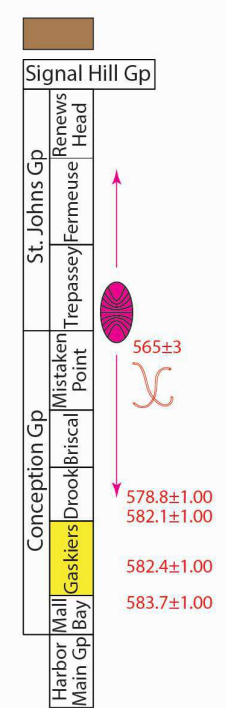
Terminal Cryogenian glacial diamictite EN1 $\delta^{13}$ Cexcursion and correlatives

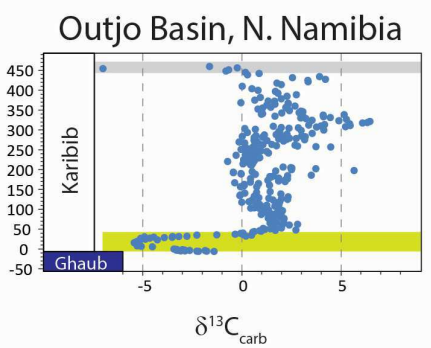

EN2 $\delta^{13}$ Cexcursion and possible correlatives

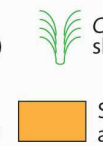
Cloudina \& related
skeletal fossils $\quad$ Trace fossils

Shuram/EN3 $\delta^{13}$ Cexcursion and potential correlatives

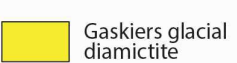

Ediacara macrofossils

Figure 5. Representative $\delta^{13} \mathrm{C}$ profiles with approximate horizons of fossil occurrences in Ediacaran successions. Oman: $\delta^{13} \mathrm{C}$ data shown in blue from Fike et al. (2006); $\delta^{13} \mathrm{C}$ data shown in red from Amthor et al. (2003). Siberia: $\delta^{13} \mathrm{C}$ data shown in blue from Ura Uplift section and $\delta^{13} \mathrm{C}$ data shown in red from Zhuya River section (Pokrovskii et al., 2006); biostratigraphic data from Sergeev et al. (2011) and Moczydlowska and Nagovitsin (2012). South Australia: $\delta^{13} \mathrm{C}$ data of the Wonoka Formation from canyon shoulder section 1 in the Flinders Ranges (Husson et al., 2015) and $\delta^{13}$ C data of the Nuccaleena Formation from Calver (2000); biostratigraphic data from Jenkins (1995), Gehling (2000), and (Grey, 2005). South China: $\delta^{13}$ C data of the Doushantuo Formation from McFadden et al. (2008) and Li et al. (2010), $\delta^{13} C$ data of Dengying Formation from Wang et al. (2014), $\delta^{13}$ C data of Yanjiahe Formation from Ishikawa et al. (2008), Jiang et al. (2012), and Ishikawa et al. (2013); biostratigraphic data from Liu et al. (2014d), Cai et al. (2010, 2015), Meyer et al. (2012), Chen et al. (2013, 2014) and Cortijo et al. (2015a). Wernecke and Mackenzie Mountains, Northwestern Canada: $\delta^{13}$ C data from Macdonald et al. (2013); radiometric date from Rooney et al. (2015); biostratigraphic data from Macdonald et al. (2013), Narbonne et al. (2014), and Carbone and Narbonne (2014). Southern Namibia: $\delta^{13} \mathrm{C}$ data shown in blue from Brak section and $\delta^{13} \mathrm{C}$ data shown in red from Zebra River section, both in Zaris Sub-basin (Wood et al., 2015); biostratigraphic data from Germs (1995), Grotzinger et al. (1995), Jensen et al. (2000), Jensen and Runnegar (2005), and Wood et al. (2015). Northern Namibia: $\delta^{13} \mathrm{C}$ data from Halverson et al. (2005). Newfoundland: biostratigraphic data from Narbonne and Gehling (2003), Liu et al. (2010), and Liu et al. (2014b). All radiometric dates are cited from Schmitz, (2012) unless otherwise noted. NK: Nikol'skoe Formation; DK: Dzhemkukan Formation; TN: Tinnaya Formation; ABC: ABC Range Quartzite; UT: Uratanna Formation; BF: Blueflower Formation; GT: Gametrail Formation; JB: June beds; YJH: Yanjiahe Formation. 
their potential as biostratigraphic markers in the Phanerozoic sense (i.e., their FAD may be useful in the definition and correlation of Ediacaran subdivisions). These include the biomineralizing animals Cloudina (Fig. 4G-H), Sinotubulites (Fig. 4I), and Namacalathus (Grant, 1990; Cai et al., 2015; Zhuravlev et al., 2015; Boag et al., in review). Among these, the tubular fossil Cloudina is the most widespread (Fig. 5), occurring in terminal Ediacaran successions in Namibia (Grant, 1990), Oman (Conway Morris et al., 1990), South China (Hua et al., 2005; Cai et al., 2013; Cortijo et al., 2015a), Spain (Cortijo et al., 2010; Cortijo et al., 2015b), Siberia (Kontorovich et al., 2008; Zhuravlev et al., 2012; Grazhdankin et al., 2015), Canada (Hofmann and Mountjoy, 2001), Mexico (Sour-Tovar et al., 2007), Brazil and Uruguay (Gaucher et al., 2003), and eastern California and Nevada where it was described as Nevadatubulus dunfeei by Signor et al. (1987) but considered as Cloudina by Grant (1990) and Zhuravlev et al. (2012). Another biomineralized tubular fossil, Sinotubulites, also has a wide geographic distribution and has been recovered from terminal Ediacaran strata in South China (Cai et al., 2015), Mexico (McMenamin, 1985), eastern California and Nevada (Signor et al., 1987), and Spain (Cortijo et al., 2015b). The colonial stalked cups of the Ediacaran shelly fossil Namacalathus was first described from Namibia (Grotzinger et al., 2000; Zhuravlev et al., 2015) and also occurs in terminal Ediacaran strata in western Canada (Hofmann and Mountjoy, 2001), Oman (Amthor et al., 2003), and Siberia (Kontorovich et al., 2008; Grazhdankin et al., 2015). Additionally, the problematic ribbon-shaped or tubular fossil Shaanxilithes have been found in terminal Ediacaran rocks in South China (Meyer et al., 2012), North China and Chaidam blocks (Shen et al., 2007), India (Tarhan et al., 2014), and Siberia (Zhuravlev et al., 2009; Cai and Hua, 2011). Finally, the organic tubular fossil Sabellidites cambriensis first appears in terminal Ediacaran rocks in the East European Platform (Moczydlowska et al., 2014), although it does extend into the basal Cambrian (Narbonne et al., 1987; Landing, 1994). These tubular fossils have the potential to improve the precision of biostratigraphic correlation of terminal Ediacaran strata. However, in order to realize their full potential as biostratigraphic markers, taxonomic issues surrounding these taxa need to be resolved. For example, the species-level taxonomy of Cloudina and Sinotubulites needs to be agreed upon (Grant, 1990; Hua et al., 2003; Cai et al., 2015), and the taxonomic relationship between Shaanxilithes and other problematic terminal Ediacaran fossils such as Nenoxites needs to be resolved (Rogov et al., 2012; Brasier et al., 2013). Additionally, high-resolution biostratigraphic study of these fossils and integration with chemostratigraphic data are required in order to project their correlation potential to areas where they are absent.

Bilaterian trace fossils are moderately abundant in many upper Ediacaran successions (Fig. 5), including the Ediacara Member of South Australia (Jenkins, 1995), the Dengying Formation in South China (Chen et al., 2013; Meyer et al., 2014b), Ediacaran rocks in the East European Platform (Paczesna, 1986; Fedonkin, 1990; Paczesna, 1996; Grazhdankin, 2014; Paczesna, 2014), the Blueflower Formation in the Mackenzie Mountains (Carbone and Narbonne, 2014), and the Nama Group in Namibia (Jensen et al., 2000; Jensen and Runnegar, 2005; Macdonald et al., 2014). In Newfoundland, structures interpreted as cnidarian traces have been found in $\sim 565$ Ma Mistaken Point Formation, representing some of the earliest known evidence for locomotive animals (Liu et al., 2010; Liu et al., 2014b). Overall, all convincing bilaterian trace fossils are restricted to upper Ediacaran rocks, but more work needs to be done in order to determine whether it is possible to select a particular ichnotaxon that has a wide geographical distribution for Ediacaran subdivision and correlation.

Macroalgal fossils have been reported from several Ediacaran successions (Xiao and Dong, 2006; Ye et al., 2015), but their stratigraphic and geographic distribution is limited by the narrow taphonomic window in which these fossils are preserved. The most diverse macroalgal assemblages come from the Lantian, Doushantuo, and Liuchapo formations in South China (Steiner, 1994; Xiao et al., 2002; Yuan et al., 2011), as well as the Khatyspyt Formation in Siberia (Grazhdankin et al., 2008) and the Perevalok Formation in the Central Urals (Grazhdankin et al., 2007; Marusin et al., 2011). Ribbon-shaped vendotaenid macrofossils are abundant in many late Ediacaran successions, including Vendian strata in the East European Platform (Gnilovskaya et al., 1988), the Dengying Formation in South China (Zhao et al., 1988), and the Feldschuhhorn Member of the Urusis Formation in southern Namibia (Cohen et al., 2009). However, these vendotaenid fossils are morphologically simple, and similar morphotypes may be present in much older rocks (Ye et al., 2015). Overall, Ediacaran macroalgal fossils are of limited biostratigraphic significance because of their restricted distribution and simple morphologies.

\section{Chemostratigraphic data}

Chemostratigraphy has been commonly used in Ediacaran stratigraphic correlation. The rapid growth of $\delta^{13} \mathrm{C}$ data, in part driven by the investigation of Ediacaran redox history and climate changes, allows us to test the global extent and stratigraphic consistency of $\delta^{13} \mathrm{C}$ variations (Fig. 5). Several authors have compiled composite $\delta^{13} \mathrm{C}$ curves for the Ediacaran Period (Halverson et al., 2005; Halverson et al., 2010; Macdonald et al., 2013). These compilations consistently show a large negative $\delta^{13} \mathrm{C}$ excursionfirst identified in the Shuram Formation in Oman (Burns and Matter, 1993) - that may be useful in global chemostratigraphic correlation of Ediacaran carbonate rocks. Possible equivalents of the Shuram excursion include the EN3 excursion in the upper Doushantuo Formation in South China, the Zhuya (=Nikol'skoe + Chencha) excursion in Siberia, the Wonoka excursion in South Australia, the Gametrail excursion in northwestern Canada, and the Kanies/Mara excursion in southern Namibia (Fig. 5 and references cited in figure caption). Additional correlatives include the Rainstorm Member in Death Valley (Kaufman et al., 2007; Bergmann et al., 2011; Verdel et al., 2011), the Member E of the Nyborg Formation in northern Norway (Halverson et al., 2005; Rice et al., 2011), and possibly the Shuiquan Formation in the Tarim block (Xiao et al., 2004), but these successions are dominated by siliciclastics and, as a result, their $\delta^{13} \mathrm{C}$ records are stratigraphically sporadic and more susceptible to isotopic mixing with authigenic carbonates (Macdonald et al., 2013; Schrag et al., 2013). Current controversies surrounding the Shuram excursion and its potential correlatives include (1) its origin: whether the Shuram excursion represents a disturbance of the global ocean DIC reservoir due to oxidation of organic carbon or methane (Rothman et al., 2003; Fike et al., 2006; Kaufman et al., 2007; McFadden et al., 2008; Bjerrum and Canfield, 2011), reflects conditions conducive to authigenic carbonate precipitation (Grotzinger et al., 2011; Macdonald et al., 2013; Schrag et al., 2013), or results from burial or meteoric diagenesis (Knauth and Kennedy, 2009; Derry, 
2010); (2) its complexity: whether the Shuram excursion consists of a simple negative anomaly (Fike et al., 2006; Le Guerroue et al., 2006; An et al., 2015) or a complex negative anomaly punctuated with one or more small-scale positive anomalies (Condon et al., 2005; Verdel et al., 2011; Lu et al., 2013; Zhou et al., in press); and (3) its age and duration: whether it is roughly concurrent with or postdates the 582 Ma Gaskiers glaciation (Fig. 3), and whether it lasted a few million years or up to 50 million years (Le Guerroue et al., 2006). These uncertainties hinder the application of the Shuram excursion in chemostratigraphic correlation of Ediacaran strata, and they are the main reasons behind the two different versions of Ediacaran subdivision (Fig. 3) (Narbonne et al., 2012b).

Strontium isotope chemostratigraphy can also be very useful in the correlation of Ediacaran carbonate strata (Fig. 6, assuming correlation model 2 in Fig. 3). Basal Ediacaran cap carbonates overlying Cryogenian glacial diamictites tend to have highly variable and sometimes highly elevated ${ }^{87} \mathrm{Sr} /{ }^{86} \mathrm{Sr}$ ratios (Sawaki et al., 2010), probably due to variable diagenetic alteration or mixing with glacial meltwaters carrying radiogenic signals derived from continental weathering (Liu et al., 2013a; Liu et al., 2014c). Assuming that the lowest ${ }^{87} \mathrm{Sr} /{ }^{86} \mathrm{Sr}$ ratios of the cap carbonates represent seawater signals, Ediacaran carbonates appear to record stepwise increase in ${ }^{87} \mathrm{Sr} /{ }^{86} \mathrm{Sr}$ ratios, first from $\sim 0.7073$ in the cap carbonates to a plateau of 0.7080 that characterizes the lower Ediacaran System, then rising to a peak of $\sim 0.7090$ roughly concurrent with the Shuram excursion, and finally falling back to 0.7085 in terminal Ediacaran (Fig. 6). Because the Sr system is sensitive to diagenetic alteration (e.g., dolomitization) and contamination from detrital components, reliable ${ }^{87} \mathrm{Sr} /{ }^{86} \mathrm{Sr}$ measurements only come from pristine limestones. This again raises the issue of cross correlation with successions dominated by dolostones and siliciclastic rocks.

\section{Geochronometric data}

Ultimately, the integration of biostratigraphy (e.g., acanthomorphs, Ediacara-type macrofossils, tubular fossils, and trace fossils) and chemostratigraphy (e.g., $\delta^{13} \mathrm{C}$ and ${ }^{87} \mathrm{Sr} /{ }^{86} \mathrm{Sr}$ ) requires radiometric dates to anchor key stratigraphic markers. Currently, highprecision radiometric dates are concentrated in the upper Ediacaran (560-541 Ma). With the exception of clustered radiometric dates in the basal Ediacaran and in the middle Ediacaran (in association with the Gaskiers glaciation), the lower-middle Ediacaran System is poorly dated globally (Fig. 3). Importantly, the Shuram/EN3 excursion and the diversification of acanthomorphs in Australia, Siberia, and the East European Platform have not been constrained with precise radiometric dates; EN3 in the uppermost Doushantuo Formation is constrained to be $>551.09 \pm 1.02 \mathrm{Ma}$ (Fig. 5), however Re-Os ages (Zhu et al., 2013a) and a radical revision of Ediacaran stratigraphic correlation in the Yangtze Gorges area (An et al., 2015) indicate that EN3 may be significantly older than $551 \mathrm{Ma}$. With these uncertainties, the alternative models of stratigraphic correlation using the Shuram excursion cannot be resolved (Fig. 3). These two models have different implications for the relative timing of biostratigraphic, chemostratigraphic, and climatic events. Most obviously, the temporal relationship between the Shuram excursion and the Gaskiers glaciation has not been resolved (Fig. 3). Critically, the temporal relationship between the Shuram excursion and the first appearance of Ediacara-type macrofossils is also uncertain. For example, assuming that the Gametrail Formation in the Wernecke Mountains (which is characterized by a pronounced negative $\delta^{13} \mathrm{C}$ excursion) and the Gametrail Formation in the Mackenzie Mountains (which records only a moderate negative $\delta^{13} \mathrm{C}$ excursion) are both equivalent to the Shuram excursion (Macdonald et al., 2013), the occurrence of rangeomorph Ediacara-type fossils in the underlying June beds in the Mackenzie Mountains (Narbonne et al., 2014) suggests the first appearance of rangeomorphs before the Shuram excursion. These rangeomorphs would postdate the Gaskiers glaciation in correlation model 1, but they predate the Gaskiers glaciation in correlation model 2 (Fig. 3). Macdonald et al. (2013) favored correlation model 1, because the June beds rangeomorph taxa are also found in strata overlying the Gaskiers Formation in Newfoundland. This proposition could be tested directly if the Shuram excursion were radiometrically dated.

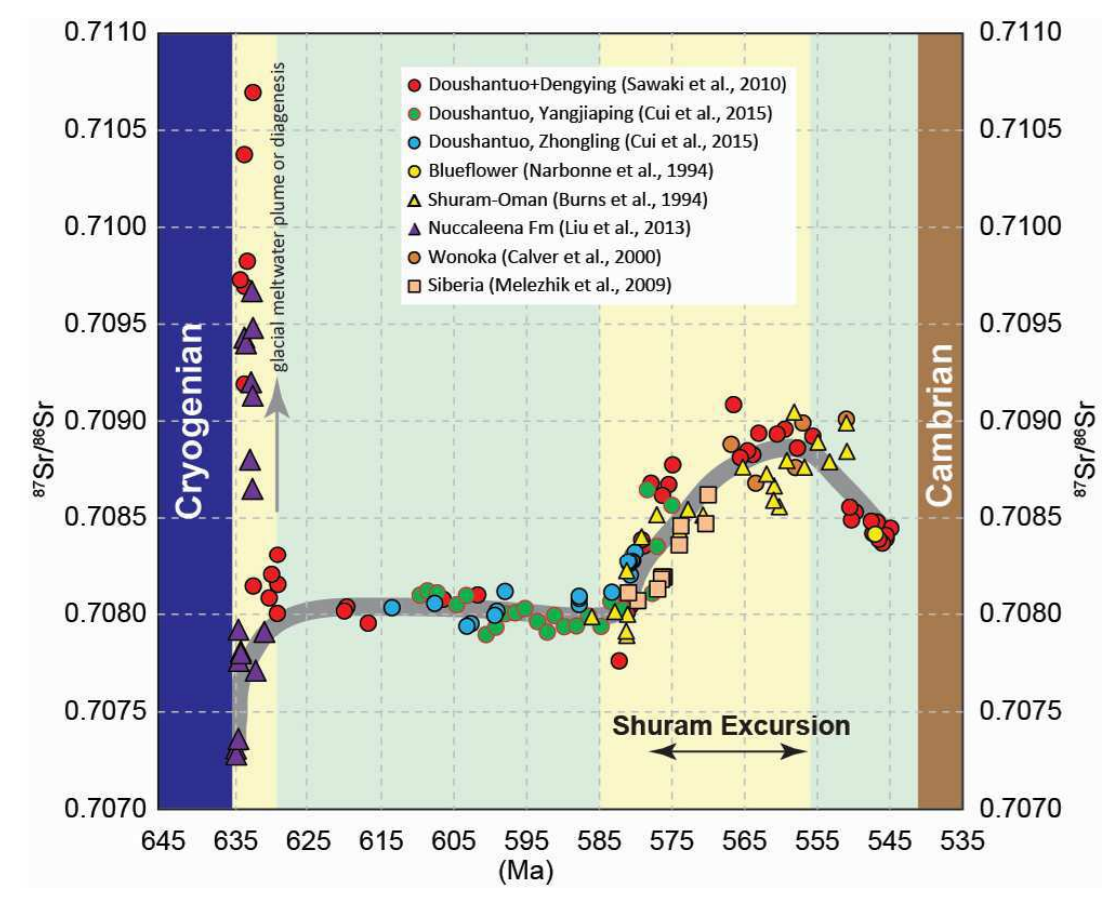

Figure 6. Compilation of Ediacaran ${ }^{87} \mathrm{Sr} /{ }^{86} \mathrm{Sr}$ data, assuming correlation model 2 (Fig. 3). Sawaki et al.'s (2010) data are screened using the criteria of carbonate wt\% $>60 \%$ and $\mathrm{Mn} / \mathrm{Sr}<1$, except those from the basal Ediacaran cap dolostone. High ${ }^{87} \mathrm{Sr} /{ }^{86} \mathrm{Sr}$ ratios of cap dolostones may have resulted from diagenetic alteration or deposition underneath glacial meltwater plumes (Liu et al., 2013a; Liu et al., 2014c), thus not representing seawater signals. Most likely seawater ${ }^{87} \mathrm{Sr} /{ }^{86} \mathrm{Sr}$ ratios are marked by thick grey line, which includes an initial rise from $\sim 0.7073$ to a plateau of 0.7080 , a second stepwise rise to a peak of $\sim 0.7090$, and then a decline to 0.7085 . The approximate age of the Shuram excursion is marked by a double-arrowheaded line. Re-Os ages (Zhu et al., 2013a) and a recently proposed correlation (An et al., 2015; but see Zhou et al., in press), if correct, imply that the Shuram excursion in South China may be significantly older than 551 Ma, more consistent with correlation model 2 (Fig. 3). ${ }^{87} \mathrm{Sr} /{ }^{86} \mathrm{Sr}$ data from Narbonne et al. (1994), Burns et al. (1994), Calver (2000), Melezhik et al. (2009), Sawaki et al. (2010), Liu et al. (2013a), and Cui et al. (2015). 


\section{Protocols and Strategies}

Recognizing the existing challenges in defining Ediacaran series, in the 2014 Wuhan workshop the Subcommission proposed that the subdivision of the Ediacaran System should proceed from the definition of stages, first focusing on the second and the terminal Ediacaran stages, where consensus is emerging with regard to stratigraphic markers of global significance. Thus, the Subcommission established the Second Ediacaran Stage Working Group (SES-WG) and the Terminal Ediacaran Stage Working Group (TES-WG) to focus on these boundaries. The establishment of these two working groups has been communicated to the Ediacaran community in the 2015 Subcommission newsletter. These working groups will organize focused symposia, field workshops, and surveys in order to (1) evaluate potential criteria for the definition of SES and TES; (2) visit, assess, and select GSSP candidates; and (3) formalize the stratigraphic names for the SES and TES, as well as the first Ediacaran stage (FES). Following the successful examples of the Subcommission on Cambrian Stratigraphy, we recommend that the informal stage names FES, SES, and TES be used in scientific communication (Fig. 3) before GSSPs and formal stage names are ratified.

The SES and TES will remain the priorities of the Subcommission in the next few years. We hope that, with the collective efforts of the community, we will be able to achieve our goal of defining the SES and TES in the near future, and then move to the next phase of defining the Ediacaran series and further subdivision of these series.

\section{Prospects}

\section{Formulating the Terminal Ediacaran Stage (TES)}

Potential criteria for recognizing the terminal Ediacaran stage (TES) are summarized above and in Fig. 3. The oldest skeletal animals in Earth history are represented by Cloudina, Sinotubulites, Namacalathus, and other terminal Ediacaran taxa. These shelly taxa are abundant and globally distributed in terminal Ediacaran strata (see above) but apparently disappear abruptly at the EdiacaranCambrian boundary (Amthor et al., 2003; but see Yang et al., 2016), enhancing their utility as index fossils for a terminal Ediacaran stage. Tubular or ribbon-shaped organic compressions are also especially abundant and diverse in rocks of terminal Ediacaran age. Of particular importance are the widely distributed taxa Vendotaenia (Cohen et al., 2009) and Sabellidites (Moczydlowska et al., 2014), although both of these taxa range into younger and/or older strata. Cambrotubulus decurvatus and Anabarites trisulcatus have been reported from rocks believed to be terminal Ediacaran in age (Nagovitsin et al., 2015; Rogov et al., 2015), but they also extend into the Cambrian, and their terminal Ediacaran occurrences need to be evaluated in conjunction with the current efforts of the Cambrian Subcommission to examine the Ediacaran-Cambrian boundary (Babcock et al., 2014). In contrast, some less widespread taxa such as Corumbella (Babcock et al., 2005), Conotubus (Cai et al., 2011; Strange and Rowland, 2015; Smith et al., 2016), Wutubus (Chen et al., 2014), and Sekwitubulus (Carbone et al., 2015) are presently known only from the terminal Ediacaran. Elucidating the taxonomy, ecology, affinities and distribution of the abundant organic tubes that characterize terminal Ediacaran strata will be critical to understanding the paleobiology of this ultimate stage of Ediacaran life.

Other biostratigraphic indicators can also be used to recognize this stage (Fig. 3). Ediacara-type fossils in the Nama assemblage are much less common and less diverse than in the earlier Avalon and White Sea assemblages, and consist mainly of a low diversity of longranging taxa such as Pteridinium and Rangea (Shen et al., 2008; Chen et al., 2014; Meyer et al., 2014a; Darroch et al., 2015; Kolesnikov et al., 2015). However, two iconic erniettomorph taxa, Swartpuntia and Ernietta, are locally abundant in and potentially restricted to terminal Ediacaran strata, although both taxa are known with certainty only from Namibia and the southwest USA (Narbonne et al., 1997; Hagadorn and Waggoner, 2000; Ivantsov et al., 2015; Elliott et al., 2016); several questionable reports of older and younger specimens require further documentation, description, and verification. Horizontal trace fossils are moderately abundant in most terminal Ediacaran successions (see above), and the oldest treptichnid burrows make their first debut in terminal Ediacaran strata (Jensen et al., 2000). In contrast to the diverse assemblages of ornamented acritarchs that permit zonation of older Ediacaran strata (Fig. 3), terminal Ediacaran strata are typified by low diversity acritarch assemblages consisting mostly of smooth leiospheres.

Chemostratigraphy and radiometric dating will be critical in defining the terminal Ediacaran stage. Carbonates in terminal Ediacaran successions typically exhibit slightly to moderately positive $\delta^{13} \mathrm{C}$ values (Wood et al., 2015; Cui et al., 2016) that lie above strongly negative $\mathrm{C}$-isotope signals potentially correlative with the Shuram anomaly (Fig. 5). Several negative $\delta^{13} \mathrm{C}$ excursions are recorded in the Ediacaran of South China (Fig. 5), emphasizing the need for multiple lines of evidence to test and confirm chemostratigraphic correlations. High-precision U-Pb dates from Namibia and South China imply that the base of the oldest Ediacaran shelly fossils in those sections is $<551 \mathrm{Ma}$ (Fig. 5), potentially providing a radiometric date for the base of the terminal Ediacaran stage.

Sections that exhibit many or most of these criteria occur in southern Africa (Namibia), Asia (South China and northeastern Siberia), Europe (Spain and northern Norway), western North America (California/Nevada, southern British Columbia, Yukon/ Northwest Territories), and eastern South America (Brazil, Paraguay). Many of these sections exhibit broad-scale intercalations of siliciclastic and carbonate strata, a feature that significantly increases our ability to integrate the multiple biostratigraphic and chemostratigraphic indicators needed to define and correlate a terminal Ediacaran stage. Site visits to key sections commenced in 2014 and will continue in the next few years. A special issue describing and integrating all major sections and correlation techniques for the terminal Ediacaran is planned for 2018, and balloting to define a GSSP for the terminal Ediacaran stage will commence a few months later.

\section{Formulating the Second Ediacaran Stage (SES)}

Fewer stratigraphic markers are available in the lower Ediacaran to define the Second Ediacaran stage. One of the stratigraphic markers of global extent is the termination of the cap dolostone overlying terminal Cryogenian glaciogenic deposits. The duration of cap dolostone deposition is no more than $10^{6}$ years (Trindade et al., 2003; Font et al., 2010), which would make the first Ediacaran stage (FES) one of the shortest in the geological time scale. It has been proposed that both the top and bottom boundaries of the cap dolostone may be diachronous (Hoffman et al., 2007); however, if the diachroneity is on the order of less than $10^{4}$ years, then the top boundary of the cap 
dolostone can still be a reasonable stratigraphic marker for global correlation.

The cap carbonate series, which includes both the cap dolostone and overlying limestone (Hoffman et al., 1998; James et al., 2001), also has a wide geographic distribution. Its duration is $\sim 3$ million years given available zircon U-Pb ages (Schmitz, 2012), including a $635.21 \pm 0.59 \mathrm{Ma}$ age from within the terminal Cryogenian glaciogenic deposits (Hoffmann et al., 2004; Prave et al., 2016), a 635.26 \pm 1.07 Ma age from within the cap dolostone (Condon et al., 2005), a $632.48 \pm 1.02 \mathrm{Ma}$ age from about $5 \mathrm{~m}$ above the cap carbonate (Condon et al., 2005), and a 632.3 \pm 5.9 Ma age from the basal Sheepbed Formation $0.9 \mathrm{~m}$ above the cap carbonate near Shale Lake in the Mackenzie Mountains (Rooney et al., 2015). If the top of the cap carbonate series is used as a marker to define the base of SES, then the FES would be $<3$ million years in duration, on a par with many Phanerozoic stage-level subdivisions. At this time scale, the kind of diachroneity discussed in Hoffman et al. (2007) would be negligible. The cap carbonate series is typically characterized by negative $\delta^{13} \mathrm{C}$ values (e.g., EN1 in South China). The cross-over to positive $\delta^{13} \mathrm{C}$ values occurs near the top of the cap carbonate series (Hoffman et al., 1998), although in South China there are many oscillations perhaps related to diagenetic alteration (McFadden et al., 2008; Tahata et al., 2013). The cap carbonate series is also characterized by a rising trend of ${ }^{87} \mathrm{Sr} /{ }^{86} \mathrm{Sr}$ ratios from $\sim 0.7073$ to 0.7080 (Fig. 6) (Halverson et al., 2007). Additionally, the FAD of Tianzhushania spinosa-thus far the earliest known Doushantuo-Pertatataka-type acanthomorphoccurs within a few meters above the cap carbonate and in close proximity to the $632.48 \pm 1.02 \mathrm{Ma}$ age (Zhou et al., 2007; McFadden et al., 2009). Thus, there are biostratigraphic, $\delta^{13} \mathrm{C}$ and ${ }^{87} \mathrm{Sr} /{ }^{86} \mathrm{Sr}$ chemostratigraphic, and unique lithostratigraphic markers clustered around a horizon dated at $632 \mathrm{Ma}$. Individually, these markers would be less useful. For example, the occurrence of Tianzhushania spinosa may be controlled by its limited biogeographic, ecological, or taphonomic distributions. This species has been reliably reported only from South China and India (Tiwari and Azmi, 1992; Joshi and Tiwari, 2016). An unnamed acanthomorph (Knoll, 1992) from Svalbard, has been synonymized with Tianzhushania spinosa (Zhang et al., 1998). Together, these biostratigraphic, chemo-stratigraphic, lithostratigraphic, and geochronological data would enable global correlation through their linkages with climatic, geochemical, and evolutionary events. This integrative approach offers the greatest potential to define the SES.

\section{Conclusions}

The subdivision and correlation of Ediacaran strata face unique challenges because of the dearth of skeletal fossils, taphonomic biases in the preservation of soft-bodied organisms, the limited number of high-precision radiometric dates, and lithofacies dependency of certain chemostratigraphic and biostratigraphic data. As such, there are currently significant challenges in dividing the Ediacaran System into two or three series (Fig. 3). The radiometrically constrained Gaskiers glaciation would be a convenient marker for series-level subdivision, but its temporal relationships with the Shuram excursion and biozones of Doushantuo-Pertatataka-type acanthomorphs are uncertain, limiting its utility as a global stratigraphic marker. Future research should focus on resolving the age, duration, and temporal relationship of key evolutionary, geochemical, and climatic events in the Ediacaran Period.
However, the multiplication of new biostratigraphic, chemostratigraphic, and geochronometric data suggests the optimism of defining the second and terminal Ediacaran stages in the near future. Terminal Ediacaran strata host a series of more or less evenly spaced and high-precision radiometric ages. There are several potential stratigraphic markers (e.g., first appearance of Cloudina, Sinotubulites, Shaanxilithes, Namacalathus, taxa of Ediacara-type macrofossils and trace fossils, and post-Shuram $\delta^{13} \mathrm{C}$ variations) that can be used to define the terminal Ediacaran stage (TES). It is more challenging to define the second Ediacaran stage (SES) because of the fewer number of reliable stratigraphic markers, but the first appearance of an acanthomorph species, the termination of cap carbonate deposition, or the end of EN1 $\delta^{13} \mathrm{C}$ excursion and its equivalents should be investigated as potential criteria to demarcate the end of the first Ediacaran stage (FES) and to define the second Ediacaran stage (SES).

\section{Acknowledgements}

The authors would like to thank Jim Gehling for his leadership of the Neoproterozoic Subcommission, which laid the foundation for the Ediacaran Subcommission. We would also like to thank Graham Shields-Zhou and Loren Babcock, chairs of the Cryogenian and Cambrian subcommissions, respectively, for their efforts to coordinate joint field workshops and symposia. Finally, we would like to thank many of our colleagues who organized and participated in Subcommission activities, including field workshops, symposia, and surveys. Mukund Sharma and Susannah Porter provided constructive reviews on an earlier version of this paper. Financial support was provided by the International Commission on Stratigraphy, National Science Foundation (EAR-1523334 to Stanley Finney; EAR-1528553 to SX), NASA Exobiology and Evolutionary Biology Program (NNX15AL27G to SX), National Natural Science Foundation of China (41272011 and 41410104004 to CZ and SX), Ministry of Science and Technology of China (2013CB835005 to CZ), Chinese Academy of Sciences (KZZD-EW-02 to CZ), Natural Sciences and Engineering Research Council of Canada (NSERC) Discovery Grants to GMN and ML, Queen's University Research Chair to GMN, Russian Science Foundation (14-17-00409 to DVG). This paper is a contribution to IGCP Project 587 "Identity, Facies and Time - The Ediacaran (Vendian) Puzzle".

\section{References}

Adamson, P.W., and Butterfield, N.J., 2014, Palaeobiology of a Doushantuotype acanthomorphic acritarch assemblage from the Ediacaran Biskopås Formation, Southern Norway: Abstracts of South China 2014: A symposium and field workshop on Ediacaran and Cryogenian Stratigraphy, p. 1-2.

Amthor, J.E., Grotzinger, J.P., Schröder, S., Bowring, S.A., Ramezani, J., Martin, M.W., and Matter, A., 2003, Extinction of Cloudina and Namacalathus at the Precambrian-Cambrian boundary in Oman: Geology, v. 31, p. 431-434.

An, Z., Jiang, G., Tong, J., Tian, L., Ye, Q., Song, H., and Song, H., 2015, Stratigraphic position of the Ediacaran Miaohe biota and its constrains on the age of the upper Doushantuo $\delta^{13} \mathrm{C}$ anomaly in the Yangtze Gorges area, South China: Precambrian Research, v. 271, p. 243-253.

Babcock, L.E., Grunow, A.M., Sadowski, G.R., and Leslie, S.A., 2005, Corumbella, an Ediacaran-grade organism from the Late Neoproterozoic of Brazil: Palaeogeography, Palaeoclimatology, Palaeoecology, v. 220, p. 7-18.

Babcock, L.E., Peng, S., Zhu, M., Xiao, S., and Ahlberg, P., 2014, Proposed 
reassessment of the Cambrian GSSP: Journal of Asian Earth Sciences, v. 98 , p. 3-10.

Bergmann, K.D., Zentmyer, R.A., and Fischer, W.W., 2011, The stratigraphic expression of a large negative carbon isotope excursion from the Ediacaran Johnnie Formation, Death Valley: Precambrian Research, v. 188, p. $45-56$.

Bingen, B., Griffin, W.L., Torsvik, T.H., and Saeed, A., 2005, Timing of Late Neoproterozoic glaciation on Baltica constrained by detrital zircon geochronology in the Hedmark Group, south-east Norway: Terra Nova, v. 17 , p. $250-258$.

Bjerrum, C.J., and Canfield, D.E., 2011, Towards a quantitative understanding of the late Neoproterozoic carbon cycle: Proceedings of the National Academy of Sciences of the United States of America, v. 108, p. 55425547.

Boag, T., Darroch, S.A.F., and Laflamme, M., in review, Ediacaran distributions in space and time: testing assemblage concepts of earliest macroscopic body fossils: Paleobiology.

Brasier, M.D., Mcllroy, D., Liu, A.G., Antcliffe, J.B., and Menon, L.R., 2013, The oldest evidence of bioturbation on Earth: Geology, v. 41, p. e289.

Burns, S.J., Haudenschild, U., and Matter, A., 1994, The strontium isotopic composition of carbonates from the late Precambrian ( 560-540 ma) Huqf Group of Oman: Chemical Geology, v. 111, p. 269-282.

Burns, S.J., and Matter, A., 1993, Carbon isotope record of the latest Proterozoic from Oman: Eclogae Geologicae Helvetiae, v. 86, p. 595-607.

Cai, Y., and Hua, H., 2011, Discussion of 'First finds of problematic Ediacaran fossil Gaojiashania in Siberia and its origin': Geological Magazine, v. 148, p. $329-333$.

Cai, Y., Hua, H., Schiffbauer, J.D., Sun, B., and Yuan, X., 2013, Tube growth patterns and microbial mat-related lifestyles in the Ediacaran fossil Cloudina, Gaojiashan Lagerstätte, South China: Gondwana Research, v. 25, p. 1008-1018.

Cai, Y., Hua, H., Xiao, S., Schiffbauer, J.D., and Li, P., 2010, Biostratinomy of the late Ediacaran pyritized Gaojiashan Lagerstätte from southern Shaanxi, South China: Importance of event deposits: Palaios, v. 25, p. 487-506.

Cai, Y., Schiffbauer, J.D., Hua, H., and Xiao, S., 2011, Morphology and paleoecology of the late Ediacaran tubular fossil Conotubus hemiannulatus from the Gaojiashan Lagerstätte of southern Shaanxi Province, South China: Precambrian Research, v. 191, p. 46-57.

Cai, Y., Xiao, S., Hua, H., and Yuan, X., 2015, New material of the biomineralizing tubular fossil Sinotubulites from the late Ediacaran Dengying Formation, South China: Precambrian Research, v. 261, p. $12-24$

Callow, R.H.T., and Brasier, M.D., 2009, Remarkable preservation of microbial mats in Neoproterozoic siliciclastic settings: Implications for Ediacaran taphonomic models: Earth Science Reviews, v. 96, p. 207219.

Calver, C.R., 2000, Isotope stratigraphy of the Ediacarian (Neoproterozoic III) of the Adelaide Rift Complex, Australia, and the overprint of water column stratification: Precambrian Research, v. 100, p. 121-150.

Calver, C.R., Black, L.P., Everard, J.L., and Seymour, D.B., 2004, U-Pb zircon age constraints on late Neoproterozoic glaciation in Tasmania: Geology, v. 10, p. $893-896$.

Carbone, C., and Narbonne, G.M., 2014, When life got smart: the evolution of behavioral complexity through the Ediacaran and early Cambrian of NW Canada: Journal of Paleontology, v. 88, p. 309-330.

Carbone, C.A., Narbonne, G.M., Macdonald, F.A., and Boag, T.H., 2015, New Ediacaran fossils from the uppermost Blueflower Formation, northwest Canada: disentangling biostratigraphy and paleoecology: Journal of Paleontology, v. 89, p. 281-291.

Chen, Z., Zhou, C., Meyer, M., Xiang, K., Schiffbauer, J.D., Yuan, X., and Xiao, S., 2013, Trace fossil evidence for Ediacaran bilaterian animals with complex behaviors: Precambrian Research, v. 224, p. 690-701.

Chen, Z., Zhou, C., Xiao, S., Wang, W., Guan, C., Hua, H., and Yuan, X., 2014, New Ediacara fossils preserved in marine limestone and their ecological implications: Scientific Reports, v. 4, p. 4180; DOI:4110.1038/ srep04180.

Cohen, P.A., Bradley, A., Knoll, A.H., Grotzinger, J.P., Jensen, S., Abelson, J., Hand, K., Love, G., Metz, J., McLoughlin, N., Meister, P., Shepard, R., Tice, M., and Wilson, J.P., 2009, Tubular compression fossils from the Ediacaran Nama Group, Namibia: Journal of Paleontology, v. 83, p. $110-122$
Condon, D., Zhu, M., Bowring, S., Wang, W., Yang, A., and Jin, Y., 2005, U$\mathrm{Pb}$ ages from the Neoproterozoic Doushantuo Formation, China: Science, v. 308 , p. $95-98$

Conway Morris, S., Mattes, B.W., and Chen, M., 1990, The early skeletal organism Cloudina: New occurrences from Oman and possibly China: American Journal of Science, v. 290-A, p. 245-260.

Cortijo, I., Cai, Y., Hua, H., Schiffbauer, J.D., and Xiao, S., 2015a, Life history and autecology of an Ediacaran index fossil: Development and dispersal of Cloudina: Gondwana Research, v. 28, p. 419-424.

Cortijo, I., Martí Mus, M., Jensen, S., and Palacios, T., 2010, A new species of Cloudina from the terminal Ediacaran of Spain: Precambrian Research, v. 176, p. 1-10.

Cortijo, I., Mus, M.M., Jensen, S., and Palacios, T., 2015b, Late Ediacaran skeletal body fossil assemblage from the Navalpino anticline, central Spain: Precambrian Research, v. 267, p. 186-195.

Cui, H., Kaufman, A.J., Xiao, S., Peek, S., Cao, H., Min, X., Cai, Y., Siegel, Z., Liu, X.-M., Peng, Y., Schiffbauer, J.D., and Martin, A.J., 2016, Environmental context for the terminal Ediacaran biomineralization of animals: Geobiology, v. 14, p. 344-363.

Cui, H., Kaufman, A.J., Xiao, S., Zhu, M., Zhou, C., and Liu, X.-M., 2015, Redox architecture of an Ediacaran ocean margin: integrated chemostratigraphic $\left(\delta^{13} \mathrm{C}-\delta^{34} \mathrm{~S}-{ }^{87} \mathrm{Sr} /{ }^{86} \mathrm{Sr}-\mathrm{Ce} / \mathrm{Ce}^{*}\right)$ correlation of the Doushantuo Formation: Chemical Geology, v. 405, p. 48-62.

Darroch, S.A.F., Laflamme, M., Schiffbauer, J.D., and Briggs, D.E.G., 2012, Experimental formation of a microbial death mask: Palaios, v. 27, p. 293-303.

Darroch, S.A.F., Sperling, E.A., Boag, T.H., Racicot, R.A., Mason, S.J., Morgan, A.S., Tweedt, S., Myrow, P., Johnston, D.T., Erwin, D.H., and Laflamme, M., 2015, Biotic replacement and mass extinction of the Ediacara biota: Proceedings of the Royal Society B (Biological Sciences), v. 282, p. 20151003.

Derry, L.A., 2010, A burial diagenesis origin for the Ediacaran ShuramWonoka carbon isotope anomaly: Earth and Planetary Science Letters, v. 294, p. $152-162$.

Elliott, D.A., Trusler, P.W., Narbonne, G.M., Vickers-Rich, P., Morton, N., Hall, M., Hoffmann, K.H., and Schneider, G.I.C., 2016, Ernietta from the Late Ediacaran Nama Group, Namibia: Journal of Paleontology, v. $89,10.1017 /$ jpa. 2016.94

Fedonkin, M.A., 1990, Paleoichnology of Vendian Metazoa, in Sokolov, B. S., and Iwanowski, A. B., eds., The Vendian System, Vol. 1: Paleontology: Heidelberg, Springer-Verlag, p. 132-137.

Fike, D.A., Grotzinger, J.P., Pratt, L.M., and Summons, R.E., 2006, Oxidation of the Ediacaran ocean: Nature, v. 444, p. 744-747.

Font, E., Nédélec, A., Trindade, R., and Moreau, C., 2010, Fast or slow melting of the Marinoan snowball Earth? The cap dolostone record: Palaeogeography, Palaeoclimatology, Palaeoecology, v. 295, p. 215225.

Gaucher, C., Boggiani, P.C., Sprechmann, P., Sial, A.N., and Fairchild, T., 2003, Integrated correlation of the Vendian to Cambrian Arroyo del Soldado and Corumbá Groups (Uruguay and Brazil): palaeogeographic, palaeoclimatic and palaeobiologic implications: Precambrian Research, v. 120 , p. $241-278$.

Gehling, J.G., 1999, Microbial mats in terminal Proterozoic siliciclastics: Ediacaran death masks: Palaios, v. 14, p. 40-57.

Gehling, J.G., 2000, Environmental interpretation and a sequence stratigraphic framework for the terminal Proterozoic Ediacara Member within the Rawnsley Quartzite, South Australia: Precambrian Research, v. 100, p. 65-95.

Gehling, J.G., and Droser, M.L., 2012, Ediacaran stratigraphy and the biota of the Adelaide Geosyncline, South Australia: Episodes, v. 35, p. 236246.

Gehling, J.G., and Droser, M.L., 2013, How well do fossil assemblages of the Ediacara Biota tell time?: Geology, v. 41, p. 447-450.

Gehling, J.G., Jago, J.B., and Paterson, J.R., 2012, Ediacaran-Cambrian of South Australia: 34th International Geological Congress (IGC) Field Trip Guide Book, p. 1-36.

Germs, G.J.B., 1995, The Neoproterozoic of southwestern Africa, with emphasis on platform stratigraphy and paleontology: Precambrian Research, v. 73, p. 137-151.

Gnilovskaya, M.B., Istchenko, A.A., Kolesniko, C.M., Korenchuk, L.V., and Udalstov, A.P., 1988, Vendotaenids of the East European Platform (in Russian), Leningrad, Nauka, 140 p. 
Golubkova, Y., E., Zaitseva, T.S., Kuznetsov, A.B., Dovzhikova, E.G., and Maslov, A.V., 2015, Microfossils and Rb-Sr age of glauconite in the key section of the upper Proterozoic of the northeastern part of the Russian Plate (Keltmen-1 Borehole): Doklady Earth Sciences, v. 462, p. 547551.

Grant, S.W.F., 1990, Shell structure and distribution of Cloudina, a potential index fossil for the terminal Proterozoic: American Journal of Science, v. 290-A, p. 261-294.

Grazhdankin, D., 2004, Patterns of distribution in the Ediacaran biotas: facies versus biogeography and evolution: Paleobiology, v. 30, p. 203-221.

Grazhdankin, D., 2014, Patterns of evolution of the Ediacaran soft-bodied biota: Journal of Paleontology, v. 88, p. 269-283.

Grazhdankin, D., and Maslov, A.V., 2015, The room for the Vendian in the international chronostratigraphic chart: Russian Geology and Geophysics, v. 56 , p. $549-559$.

Grazhdankin, D.V., Balthasar, U., Nagovitsin, K.E., and Kochnev, B.B., 2008, Carbonate-hosted Avalon-type fossils in Arctic Siberia: Geology, v. 36, p. 803-806.

Grazhdankin, D.V., Kontorovich, A.E., Kontorovich, V.A., Saraev, S.V., Filippov, F., Yu., Efimov, A.S., Karlova, G.A., Kochnev, B.B., Nagovitsin, K.E., Terleev, A.A., and Fedyanin, G.O., 2015, Vendian of the Fore-Yenisei sedimentary basin (southeastern West Siberia): Russian Geology and Geophysics, v. 56, p. 560-572.

Grazhdankin, D.V., Nagovitsin, K.E., and Maslov, A.V., 2007, Upper Vendian Miaohe-type ecological assemblage of the East European Platform: Doklady Earth Sciences, v. 417, p. 1183-1187.

Grey, K., 2005, Ediacaran palynology of Australia: Memoirs of the Association of Australasian Palaeontologists, v. 31, p. 1-439.

Grey, K., and Willman, S., 2009, Taphonomy of Ediacaran acritarchs from Australia: Significance for taxonomy and biostratigraphy: Palaios, v. 24, p. $239-256$

Grotzinger, J.P., Bowring, S.A., Saylor, B.Z., and Kaufman, A.J., 1995, Biostratigraphic and geochronologic constraints on early animal evolution: Science, v. 270, p. 598-604.

Grotzinger, J.P., Fike, D.A., and Fischer, W.W., 2011, Enigmatic origin of the largest-known carbon isotope excursion in Earth's history: Nature Geoscience, v. 4, p. 285-292.

Grotzinger, J.P., Watters, W.A., and Knoll, A.H., 2000, Calcified metazoans in thrombolite-stromatolite reefs of the terminal Proterozoic Nama Group, Namibia: Paleobiology, v. 26, p. 334-359.

Hagadorn, J.W., and Waggoner, B.M., 2000, Ediacaran fossils from the southwestern Great Basin, United States: Journal of Paleontology, v. 74, p. 349-359.

Halverson, G.P., Dudás, F.Ö., Maloof, A.C., and Bowring, S.A., 2007, Evolution of the ${ }^{87} \mathrm{Sr} /{ }^{86} \mathrm{Sr}$ Composition of Neoproterozoic Seawater: Palaeogeography Palaeoclimatology Palaeoecology, v. 256, p. 103-129.

Halverson, G.P., Hoffman, P.F., Schrag, D.P., Maloof, A.C., and Rice, A.H.N., 2005, Toward a Neoproterozoic composite carbon-isotope record: GSA Bulletin, v. 117, p. 1181-1207; doi: 1110.1130/B25630.25631.

Halverson, G.P., Wade, B.P., Hurtgen, M.T., and Barovich, K.M., 2010, Neoproterozoic chemostratigraphy: Precambrian Research, v. 182, p. 337-350.

Hoffman, P.F., Halverson, G.P., Domack, E.W., Husson, J.M., Higgins, J.A., and Schrag, D.P., 2007, Are basal Ediacaran (635 Ma) post-glacial "cap dolostones" diachronous?: Earth and Planetary Science Letters, v. 258, p. 114-131.

Hoffman, P.F., Kaufman, A.J., Halverson, G.P., and Schrag, D.P., 1998, A Neoproterozoic snowball Earth: Science, v. 281, p. 1342-1346.

Hoffman, P.F., and Li, Z.-X., 2009, A palaeogeographic context for Neoproterozoic glaciation: Palaeogeography Palaeoclimatology Palaeoecology, v. 277, p. 158-172.

Hoffmann, K.-H., Condon, D.J., Bowring, S.A., and Crowley, J.L., 2004, U$\mathrm{Pb}$ zircon date from the Neoproterozoic Ghaub Formation, Namibia: Constraints on Marinoan glaciation: Geology, v. 32, p. 817-820.

Hofmann, H.J., and Mountjoy, E.W., 2001, Namacalathus-Cloudina assemblage in Neoproterozoic Miette Group (Byng Formation), British Columbia: Canada's oldest shelly fossils: Geology, v. 29, p. 1091-1094.

Hua, H., Chen, Z., Yuan, X., Zhang, L., and Xiao, S., 2005, Skeletogenesis and asexual reproduction in the earliest biomineralizing animal Cloudina: Geology, v. 33, p. 277-280.

Hua, H., Chen, Z., and Zhang, L., 2004, Shaanxilithes from lower Taozichong Formation, Guizhou Province and its geological and paleobiological significance: Journal of Stratigraphy, v. 28, p. 265-269.

Hua, H., Pratt, B.R., and Zhang, L., 2003, Borings in Cloudina shells: Complex predator-prey dynamics in the terminal Neoproterozoic: Palaios, v. 18, p. 454-459.

Husson, J.M., Maloof, A.C., Schoene, B., Chen, C.Y., and Higgins, J.A., 2015, Stratigraphic expression of Earth's deepest $\mathrm{d}^{13} \mathrm{C}$ excursion in the Wonoka Formation of South Australia: American Journal of Science, v. 315 , p. $1-45$

Ishikawa, T., Ueno, Y., Komiya, T., Sawaki, Y., Han, J., Shu, D., Li, Y., Maruyama, S., and Yoshida, N., 2008, Carbon isotope chemostratigraphy of a Precambrian/Cambrian boundary section in the Three Gorge area, South China: Prominent global-scale isotope excursions just before the Cambrian Explosion: Gondwana Research, v. 14, p. 193-208.

Ishikawa, T., Ueno, Y., Shu, D., Li, Y., Han, J., Guo, J., Yoshida, N., Maruyama, S., and Komiya, T., 2013, The $\mathrm{d}^{13} \mathrm{C}$ excursions spanning the Cambrian explosion to the Canglangpuian mass extinction in the Three Gorges area, South China: Gondwana Research, v. doi:10.1016/j.gr.2013.03.010.

Ivantsov, A.Y., Narbonne, G.M., Trusler, P.W., Greentree, C., and VickersRich, P., 2015, Elucidating Ernietta: new insights from exceptional specimens in the Ediacaran of Namibia: Lethaia, v. 49, p. 540-554.

James, N.P., Narbonne, G.M., and Kyser, T.K., 2001, Late Neoproterozoic cap carbonates: Mackenzie Mountains, Northwestern Canada: Precipitation and global glaciation meltdown: Canadian Journal of Earth Sciences, v. 38, p. 1229-1262.

Jenkins, R.J.F., 1995, The problems and potential of using animal fossils and trace fossils in terminal Proterozoic biostratigraphy: Precambrian Research, v. 73, p. 51-69.

Jensen, S., and Runnegar, B.N., 2005, A complex trace fossil from the Spitskop Member (terminal Ediacaran-? Lower Cambrian) of southern Namibia: Geological Magazine, v. 142, p. 561-569.

Jensen, S., Saylor, B.Z., Gehling, J.G., and Germs, G.J.B., 2000, Complex trace fossils from the terminal Proterozoic of Namibia: Geology, v. 28, p. 143-146.

Jiang, G., Kaufman, A.J., Christie-Blick, N., Zhang, S., and Wu, H., 2007, Carbon isotope variability across the Ediacaran Yangtze platform in South China: Implications for a large surface-to-deep ocean $\delta^{13} \mathrm{C}$ gradient: Earth and Planetary Science Letters, v. 261, p. 303-320.

Jiang, G., Wang, X., Shi, X., and Xiao, S., 2012, The origin of decoupled carbonate and organic carbon isotope signatures in the early Cambrian (ca. 542-520 Ma) Yangtze platform: Earth and Planetary Science Letters, v. 317-318, p. 96-110.

Joshi, H., and Tiwari, M., 2016, Tianzhushania spinosa and other large acanthomorphic acritarchs of Ediacaran Period from the Infrakrol Formation, Lesser Himalaya, India: Precambrian Research, 10.1016/ j.precamres.2016.09.024.

Kaufman, A.J., Corsetti, F.A., and Varni, M.A., 2007, The effect of rising atmospheric oxygen on carbon and sulfur isotope anomalies in the Neoproterozoic Johnnie Formation, Death Valley, USA: Chemical Geology, v. 237, p. 47-63.

Kaufman, A.J., Vickers-Rich, P., Walde, D., Gaucher, C., and Boggiani, P.C., 2014, Corumba Meeting 2013: The Neoproterozoic Paraguay Fold Belt (Brazil): Glaciation, iron-manganese formation and biota, an IGCP workshop and field excursion on the Ediacaran System: Episodes, v. 37, p. 71-73.

Kenchington, C.G., and Wilby, P.R., 2014, Of time and taphonomy: Preservation in the Ediacaran, in Laflamme, M., Darroch, S. A. F., and Schiffbauer, J. D., eds., Reading and Writing of the Fossil Record: Preservational Pathways to Exceptional Fossilization (The Paleontological Society Papers Volume 20), p. 101-122.

Knauth, L.P., and Kennedy, M.J., 2009, The late Precambrian greening of the Earth: Nature, v. 460, p. 728-732.

Knoll, A.H., 1992, Microfossils in metasedimentary cherts of the Scotia Group, Prins Karls Forland, western Svalbard: Palaeontology, v. 35, p. 751-774.

Knoll, A.H., Walter, M.R., Narbonne, G.M., and Christie-Blick, N., 2004, A new period for the geologic time scale: Science, v. 305, p. 621-622.

Knoll, A.H., Walter, M.R., Narbonne, G.M., and Christie-Blick, N., 2006, The Ediacaran Period: a new addition to the geologic time scale: Lethaia, v. 39, p. 13-30.

Kolesnikov, A.V., Marusin, V.V., Nagovitsin, K.E., Maslov, A.V., and Grazhdankin, D.V., 2015, Ediacaran biota in the aftermath of the Kotlinian Crisis:Asha Group of the South Urals: Precambrian Research, v. 263 , p. $59-78$. 
Kontorovich, A.E., Varlamov, A.I., Grazhdankin, D.V., Karlova, G.A., Klets, A.G., Kontorovich, V.A., Saraev, S.V., Terleev, A.A., Belyaev, S.Y., Varaksina, I.V., Efimov, A.S., Kochnev, B.B., Nagovitsin, K.E., Postnikov, A.A., and Filippov, Y.F., 2008, A section of Vendian in the east of West Siberian Plate (based on data from the Borehole Vostok 3): Russian Geology and Geophysics, v. 49, p. 932-939.

Kumar, S., and Sharma, M., 2010, Field Guide, Vindhyan Basin, Son Valley Area, Central India, Lucknow, The Palaeontological Society of India, $107 \mathrm{p}$.

Kumar, S., and Sharma, M., 2012, Palaeontological Society of India Field Guide: Vindhyan Basin, Son Valley Area, Central India, Lucknow, The Palaeontological Society of India, $145 \mathrm{p}$.

Laflamme, M., Darroch, S.A.F., Tweedt, S.M., Peterson, K.J., and Erwin, D.H., 2013, The end of the Ediacara biota: Extinction, biotic replacement, or Cheshire Cat?: Gondwana Research, v. 23, p. 558-573.

Laflamme, M., Schiffbauer, J.D., Narbonne, G.M., and Briggs, D.E.G., 2011, Microbial biofilms and the preservation of the Ediacara biota: Lethaia, v. 44 , p. $203-213$.

Landing, E., 1994, Precambrian-Cambrian boundary global stratotype ratified and a new perspective of Cambrian time: Geology, v. 22, p. 179-182.

Le Guerroue, E., Allen, P.A., Cozzi, A., Etienne, J.L., and Fanning, M., 2006, $50 \mathrm{Myr}$ recovery from the largest negative $\mathrm{d}^{13} \mathrm{C}$ excursion in the Ediacaran ocean: Terra Nova, v. 18, p. 147-153.

Li, C., Love, G.D., Lyons, T.W., Fike, D.A., Sessions, A.L., and Chu, X., 2010, A stratified redox model for the Ediacaran ocean: Science, v. 328, p. $80-83$.

Li, Z.-X., Evans, D.A.D., and Halverson, G.P., 2013, Neoproterozoic glaciations in a revised global palaeogeography from the breakup of Rodinia to the assembly of Gondwanaland: Sedimentary Geology, v. 294, p. 219-232.

Liu, A.G., Kenchington, C.G., and Mitchell, E.G., 2014a, Remarkable insights into the paleoecology of the Avalonian Ediacaran macrobiota: Gondwana Research, v. 27, p. 1355-1380.

Liu, A.G., McIlroy, D., and Brasier, M.D., 2010, First evidence for locomotion in the Ediacara biota from the 565 Ma Mistaken Point Formation, Newfoundland: Geology, v. 38, p. 123-126.

Liu, A.G., McIlroy, D., Matthews, J.J., and Brasier, M.D., 2014b, Confirming the metazoan character of a 565 ma trace-fossil assemblage from Mistaken Point, Newfoundland: Palaios, v. 29, p. 420-430.

Liu, C., Wang, Z., and Raub, T.D., 2013a, Geochemical constraints on the origin of Marinoan cap dolostones from Nuccaleena Formation, South Australia: Chemical Geology, v. 351, p. 95-104.

Liu, C., Wang, Z., Raub, T.D., Macdonald, F.A., and Evans, D.A.D., 2014c, Neoproterozoic cap-dolostone deposition in stratified glacial meltwater plume: Earth and Planetary Science Letters, v. 404, p. 22-32.

Liu, P., Xiao, S., Yin, C., Chen, S., Zhou, C., and Li, M., 2014d, Ediacaran acanthomorphic acritarchs and other microfossils from chert nodules of the upper Doushantuo Formation in the Yangtze Gorges area, South China: Journal of Paleontology, v. 72 (supplement to No 1), p. 1-139.

Liu, P., Yin, C., Chen, S., Tang, F., and Gao, L., 2013b, The biostratigraphic succession of acanthomorphic acritarchs of the Ediacaran Doushantuo Formation in the Yangtze Gorges area, South China and its biostratigraphic correlation with Australia: Precambrian Research, v. 225, p. 29-43.

Lu, M., Zhu, M., Zhang, J., Shields-Zhou, G., Li, G., Zhao, F., Zhao, X., and Zhao, M., 2013, The DOUNCE event at the top of the Ediacaran Doushantuo Formation, South China: Broad stratigraphic occurrence and non-diagenetic origin: Precambrian Research, v. 225, p. 86-109.

Macdonald, F.A., Pruss, S.B., and Strauss, J.V., 2014, Trace fossils with spreiten from the late Ediacaran Nama Group, Namibia: complex feeding patterns five million years before the precambrian-cambrian boundary: Journal of Paleontology, v. 88, p. 299-308.

Macdonald, F.A., Strauss, J.V., Sperling, E.A., Halverson, G.P., Narbonne, G.M., Johnston, D.T., Kunzmann, M., Schrag, D.P., and Higgins, J.A., 2013, The stratigraphic relationship between the Shuram carbon isotope excursion, the oxygenation of Neoproterozoic oceans, and the first appearance of the Ediacara biota and bilaterian trace fossils in northwestern Canada: Chemical Geology, v. 362, p. 250-272.

Marusin, V.V., Grazhdankin, D.V., and Maslov, A.V., 2011, Redkino Stage in evolution of Vendian macrophytes: Doklady Earth Sciences, v. 436, p. 197-202.

McFadden, K.A., Huang, J., Chu, X., Jiang, G., Kaufman, A.J., Zhou, C.,
Yuan, X., and Xiao, S., 2008, Pulsed oxygenation and biological evolution in the Ediacaran Doushantuo Formation: Proceedings of the National Academy of Sciences, USA, v. 105, p. 3197-3202.

McFadden, K.A., Xiao, S., Zhou, C., and Kowalewski, M., 2009, Quantitative evaluation of the biostratigraphic distribution of acanthomorphic acritarchs in the Ediacaran Doushantuo Formation in the Yangtze Gorges area, South China: Precambrian Research, v. 173, p. 170-190.

McMenamin, M.A.S., 1985, Basal Cambrian small shelly fossils from the La Ciénega Formation, northwestern Sonora, Mexico: Journal of Paleontology, v. 59, p. 1414-1425.

Melezhik, V.A., Pokrovsky, B.G., Fallick, A.E., Kuznetsov, A.B., and Bujakaite, M.I., 2009, Constraints on ${ }^{87} \mathrm{Sr} /{ }^{86} \mathrm{Sr}$ of late Ediacaran seawater: insight from Siberian high-Sr limestones: Journal of the Geological Society, v. 166, p. 183-191.

Meyer, M., Elliott, D., Wood, A.D., Polys, N.F., Colbert, M., Maisano, J.A., Vickers-Rich, P., Hall, M., Hoffman, K.H., Schneider, G., and Xiao, S., 2014a, Three-dimensional microCT analysis of the Ediacara fossil Pteridinium simplex sheds new light on its ecology and phylogenetic affinity: Precambrian Research, v. 249, p. 79-87.

Meyer, M., Schiffbauer, J.D., Xiao, S., Cai, Y., and Hua, H., 2012, Taphonomy of the upper Ediacaran enigmatic ribbon-like fossil Shaanxilithes: Palaios, v. 27 , p. $354-372$.

Meyer, M., Xiao, S., Schiffbauer, J.D., Chen, Z., Zhou, C., and Yuan, X., 2014b, Lamonte trevallis, a new trace fossil from the Dengying Formation of South China: insights into late Ediacaran benthic ecology: Geological Society of America Abstracts with Programs, v. 46(3), p. 86.

Moczydlowska-Vidal, M., Grey, K., Xiao, S., and Willman, S., 2008, Swedish workshop on Ediacaran acritarch taxonomy (SWEATSHOP): Episodes, v. 31, p. 442.

Moczydlowska, M., and Nagovitsin, K.E., 2012, Ediacaran radiation of organic-walled microbiota recorded in the Ura Formation, Patom Uplift, East Siberia: Precambrian Research, v. 198-199, p. 1-24.

Moczydlowska, M., Vidal, G., and Rudavskaya, V.A., 1993, Neoproterozoic (Vendian) phytoplankton from the Siberian Platform, Yakutia: Palaeontology, v. 36, p. 495-521.

Moczydlowska, M., Westall, F., and Foucher, F., 2014, Microstructure and biogeochemistry of the organically preserved Ediacaran metazoan Sabellidites: Journal of Paleontology, v. 88, p. 224-239.

Muscente, A.D., Hawkins, A.D., and Xiao, S., 2015, Fossil preservation through phosphatization and silicification in the Ediacaran Doushantuo Formation (South China): A comparative synthesis: Palaeogeography Palaeoclimatology Palaeoecology, v. 434, p. 46-62.

Myrow, P.M., and Kaufman, A.J., 1999, A newly discovered cap carbonate above Varanger-aged glacial deposits in Newfoundland, Canada: Journal of Sedimentary Research, v. 69, p. 784-793.

Nagovitsin, K.E., and Kochnev, B.B., 2015, Microfossils and biofacies of the Vendian fossil biota in the southern Siberian Platform: Russian Geology and Geophysics, v. 56, p. 584-593.

Nagovitsin, K.E., Rogov, V.I., Marusin, V.V., Karlova, G.A., Kolesnikov, A.V., Bykova, N.V., and Grazhdankin, D.V., 2015, Revised Neoproterozoic and Terreneuvian stratigraphy of the Lena-Anabar Basin and northwestern slope of the Olenek Uplift, Siberian Platform: Precambrian Research, v. 270, p. 226-245.

Narbonne, G.M., 2005, The Ediacara Biota: Neoproterozoic origin of animals and their ecosystems: Annual Review of Earth and Planetary Sciences, v. 33 , p. $421-442$.

Narbonne, G.M., and Gehling, J.G., 2003, Life after snowball: The oldest complex Ediacaran fossils: Geology, v. 31, p. 27-30.

Narbonne, G.M., Kaufman, A.J., and Knoll, A.H., 1994, Integrated chemostratigraphy and biostratigraphy of the Windermere Supergroup, northwestern Canada: implications for Neoproterozoic correlations and the early evolution of animals: GSA Bulletin, v. 106, p. 1281-1292.

Narbonne, G.M., Laflamme, M., Greentree, C., and Trusler, P., 2009, Reconstructing a lost world: Ediacaran rangeomorphs from Spaniard's Bay, Newfoundland: Journal of Paleontology, v. 83, p. 503-523.

Narbonne, G.M., Laflamme, M., and Thomas, R., 2012a, When life got big: glaciation, oxidation, and the Mistaken Point biota of Newfoundland: Geological Association of Canada Field Trip Guidebook, v. B1, p. 1-78.

Narbonne, G.M., Laflamme, M., Trusler, P.W., Dalrymple, R.W., and Greentree, C., 2014, Deep-water Ediacaran fossils from northwestern Canada: taphonomy, ecology, and evolution: Journal of Paleontology, v. 88 , p. 207-223. 
Narbonne, G.M., Myrow, P.M., Landing, E., and Anderson, M.M., 1987, A candidate stratotype for the Precambrian-Cambrian boundary, Fortune Head, Burin Peninsula, southeastern Newfoundland: Canadian Journal of Earth Sciences, v. 24, p. 1277-1293.

Narbonne, G.M., Saylor, B.Z., and Grotzinger, J.P., 1997, The youngest Ediacaran fossils from southern Africa: Journal of Paleontology, v. 71, p. $953-967$.

Narbonne, G.M., Xiao, S., and Shields, G.A., 2012b, The Ediacaran Period, in Gradstein, F. M., Ogg, J. G., Schmitz, M., and Ogg, G., eds., Geological Time Scale 2012: Oxford, Elsevier, p. 413-435.

Noble, S.R., Condon, D.J., Carney, J.N., Wilby, P.R., Pharaoh, T.C., and Ford, T.D., 2015, U-Pb geochronology and global context of the Charnian Supergroup, UK: Constraints on the age of key Ediacaran fossil assemblages: Geological Society of America Bulletin, v. 127, p. 250265.

Paczesna, J., 1986, Upper Vendian and Lower Cambrian ichnoceonoses of Lublin region: Biuletyn Instytutu Geologicznego 355, Geology of Poland, v. VII, p. 31-48

Paczesna, J., 1996, Upper Vendian and Cambrian ichnoceonoses from Polish part of the East European Platform: Prace Panstwowego Instytutu Geologicznego, v. 152, p. 1-77.

Paczesna, J., 2014, Lithostratigraphy of the Ediacaran deposits in the LublinPodlasie sedimentary basin (Eastern and southeaster Poland): Biuletyn Panstwowego Instytutu Geologicznego, v. 460, p. 1-23.

Pandey, S.K., and Dimri, B., 2014, Field workshop on the Marwar Supergroup: Current Science, v. 107, p. 169-170.

Pokrovskii, B.G., Melezhik, V.A., and Bujakaite, M.I., 2006, Carbon, oxygen, strontium, and sulfur isotopic compositions in late Precambrian rocks of the Patom Complex, central Siberia: Communication 1. results, isotope stratigraphy, and dating problems: Lithology and Mineral Resources, v. 41 , p. $450-474$

Prave, A.R., Condon, D.J., Hoffmann, K.H., Tapster, S., and Fallick, A.E., 2016, Duration and nature of the end-Cryogenian (Marinoan) glaciation: Geology, v. 44, p. 631-634.

Rice, A.H.N., Edwards, M.B., Hansen, T.A., Arnaud, E., and Halverson, G.P., 2011, Glaciogenic rocks of the Neoproterozoic Smalfjord and Mortensnes formations, Vestertana Group, E. Finnmark, Norway, in Arnaud, E., Halverson, G. P., and Shields-Zhou, G., eds., The Geological Record of Neoproterozoic Glaciations: London, Geological Society of London.

Rogov, V., Marusin, V., Bykova, N., Goy, Y., Nagovitsin, K., Kochnev, B., Karlova, G., and Grazhdankin, D., 2012, The oldest evidence of bioturbation on Earth: Geology, v. 40, p. 395-398.

Rogov, V.I., Karlova, G.A., Marusin, V.V., Kochnev, B.B., Nagovitsin, K.E., and Grazhdankin, D.V., 2015, Duration of the first biozone in the Siberian hypostratotype of the Vendian: Russian Geology and Geophysics, v. 56, p. 573-583.

Rooney, A.D., Strauss, J.V., Brandon, A.D., and Macdonald, F.A., 2015, A Cryogenian chronology: Two long-lasting synchronous Neoproterozoic glaciations: Geology, v. 43, p. 459-462.

Rothman, D.H., Hayes, J.M., and Summons, R., 2003, Dynamics of the Neoproterozoic carbon cycle: Proceedings of the National Academy of Sciences, USA, v. 100, p. 8124-8129.

Sawaki, Y., Ohno, T., Tahata, M., Komiya, T., Hirata, T., Maruyama, S., Windley, B.F., Han, J., Shu, D., and Li, Y., 2010, The Ediacaran radiogenic $\mathrm{Sr}$ isotope excursion in the Doushantuo Formation in the Three Gorges area, South China: Precambrian Research, v. 176, p. 46-64.

Schmitz, M.D., 2012, Appendix 2-Radiometric ages used in GTS2012, in Gradstein, F., Ogg, J., Schmitz, M. D., and Ogg, G., eds., The Geologic Time Scale 2012: Boston, Elsevier, p. 1045-1082.

Schrag, D.P., Higgins, J.A., Macdonald, F.A., and Johnston, D.T., 2013, Authigenic carbonate and the history of the global carbon cycle: Science, v. 339, p. 540-543.

Sergeev, V.N., Knoll, A.H., and Vorob'Eva, N.G., 2011, Ediacaran microfossils from the Ura Formation, Baikal-Patom Uplift, Siberia: taxonomy and biostratigraphic significance: Journal of Paleontology, v. 85, p. 987-1011.

Shen, B., Dong, L., Xiao, S., and Kowalewski, M., 2008, The Avalon explosion: Evolution of Ediacara morphospace: Science, v. 319, p. 81-84.

Shen, B., Xiao, S., Dong, L., Zhou, C., and Liu, J., 2007, Problematic macrofossils from Ediacaran successions in the North China and Chaidam blocks: Implications for their evolutionary roots and biostratigraphic significance: Journal of Paleontology, v. 81, p. 1396-1411.

Shukla, R., and Tiwari, M., 2014, Ediacaran acanthomorphic acritarchs from the Outer Krol Belt, Lesser Himalaya, India: Their significance for global correlation: Palaeoworld, v. 23, p. 209-224.

Signor, P.W., Mount, J.F., and Onken, B.R., 1987, A pre-trilobite shelly fauna from the White-Inyo region of eastern California and western Nevada: Journal of Paleontology, v. 61, p. 425-438.

Singh, V.K., and Ansari, A.H., 2014, A report on the international field workshop on the Marwar Supergroup, Rajasthan, western India, 20th28th January, 2014: Journal of the Palaeontological Society of India, v. 59, p. 113-114.

Smith, E.F., Nelson, L.L., Strange, M.A., Eyster, A.E., Rowland, S.M., Schrag, D.P., and Macdonald, F.A., 2016, The end of the Ediacaran: Two new exceptionally preserved body fossil assemblages from Mount Dunfee, Nevada, USA: Geology, v. 44, p. 911-914.

Sour-Tovar, F., Hagadorn, J.W., and Huitrón-Rubio, T., 2007, Ediacaran and Cambrian index fossils from Sonora, Mexico: Palaeontology, v. 50, p. $169-175$.

Steiner, M., 1994, Die neoproterozoischen Megaalgen Südchinas: Berliner geowissenschaftliche Abhandlungen (E), v. 15, p. 1-146.

Strange, M.A., and Rowland, S.M., 2015, First report of the Ediacaran cloudinid fossil Conotubus in North America and its apparent preservation by direct precipitation of iron oxides and iron-rich aluminosilicates: Geological Society of America Abstracts with Programs, v. 47(7), p. 572.

Sun, W., 1986, Late Precambrian pennatulids (sea pens) from the eastern Yangtze Gorge, China: Paracharnia gen. nov.: Precambrian Research, v. 31, p. 361-375.

Tahata, M., Ueno, Y., Ishikawa, T., Sawaki, Y., Murakami, K., Han, J., Shu, D., Li, Y., Guo, J., Yoshida, N., and Komiya, T., 2013, Carbon and oxygen isotope chemostratigraphies of the Yangtze platform, South China: Decoding temperature and environmental changes through the Ediacaran: Gondwana Research, v. 23, p. 333-353.

Tarhan, L.G., Hughes, N.C., Myrow, P.M., Bhargava, O.N., Ahluwalia, A.D., and Kudryavtsev, A.B., 2014, Precambrian-Cambrian boundary interval occurrence and form of the enigmatic tubular body fossil Shaanxilithes ningqiangensis from the Lesser Himalaya of India: Palaeontology, v. 57, p. 283-298.

Thompson, M.D., and Bowring, S.A., 2000, Age of the Squantum "tillite", Boston Basin, Massachusetts: U-Pb zircon constraints on terminal Neoproterozoic glaciation: American Journal of Science, v. 300, p. 630655.

Tiwari, M., and Azmi, R.J., 1992, Late Proterozoic organic-walled microfossils from the Infrakrol of Solan, Himchal Lesser Himalaya: An additional age constraint in the Krol Belt succession: Palaeobotanist, v. 39, p. 387394.

Trindade, R., Font, E., D’Agrella-Filho, M., Nogueira, A., and Riccomini, C., 2003, Low-latitude and multiple geomagnetic reversals in the Neoproterozoic Puga cap carbonate, Amazon craton: Terra Nova, v. 15, p. 441-446.

Verdel, C., Wernicke, B.P., and Bowring, S.A., 2011, The Shuram and subsequent Ediacaran carbon isotope excursions from southwest Laurentia, and implications for environmental stability during the metazoan radiation: Geological Society of America Bulletin, v. 123, p. $1539-1559$.

Vidal, G., 1990, Giant acanthomorph acritarchs from the upper Proterozoic in southern Norway: Palaeontology, v. 33, p. 287-298.

Vorob'eva, N.G., Sergeev, V.N., and Knoll, A.H., 2009, Neoproterozoic microfossils from the northeastern margin of the East European Platform: Journal of Paleontology, v. 83, p. 161-196.

Waggoner, B., 1999, Biogeographic analyses of the Ediacara biota; a conflict with paleotectonic reconstructions: Paleobiology, v. 25, p. 440-458.

Waggoner, B., 2003, The Ediacaran biotas in space and time: Integrative and Comparative Biology, v. 43, p. 104-113.

Wang, X.Q., Shi, X.Y., Jiang, G.Q., and Tang, D.J., 2014, Organic carbon isotope gradient and ocean stratification across the late Ediacaran-Early Cambrian Yangtze Platform: Science China-Earth Sciences, v. 57, p. 919929.

Willman, S., 2007, Acritarchs and their potential in Ediacaran biostratigraphy - Examples from the Officer Basin, Australia: Comunicações Geológicas, v. 94 , p. 81-92.

Willman, S., and Moczyd ${ }^{3}$ owska, M., 2008, Ediacaran acritarch biota from the Giles 1 drillhole, Officer Basin, Australia, and its potential for biostratigraphic correlation: Precambrian Research, v. 162, p. 498-530.

Willman, S., and Moczyd³0wska, M., 2011, Acritarchs in the Ediacaran of 
Australia - Local or global significance? Evidence from the Lake Maurice West 1 drillcore: Review of Palaeobotany and Palynology, v. 166, p. 1228.

Willman, S., Moczyd³3owska, M., and Grey, K., 2006, Neoproterozoic (Ediacaran) diversification of acritarchs: A new record from the Murnaroo 1 drillcore, eastern Officer Basin, Australia: Review of Palaeobotany and Palynology, v. 139, p. 17-39.

Wood, R.A., Poulton, S.W., Prave, A.R., Hoffmann, K.H., Clarkson, M.O., Guilbaud, R., Lyne, J.W., Tostevin, R., Bowyer, F., Penny, A.M., Curtis, A., and Kasemann, S.A., 2015, Dynamic redox conditions control late Ediacaran metazoan ecosystems in the Nama Group, Namibia: Precambrian Research, v. 261, p. 252-271.

Xiao, S., Bao, H., Wang, H., Kaufman, A.J., Zhou, C., Li, G., Yuan, X., and Ling, H., 2004, The Neoproterozoic Quruqtagh Group in eastern Chinese Tianshan: Evidence for a post-Marinoan glaciation: Precambrian Research, v. 130, p. 1-26.

Xiao, S., and Dong, L., 2006, On the morphological and ecological history of Proterozoic macroalgae, in Xiao, S., and Kaufman, A. J., eds., Neoproterozoic Geobiology and Paleobiology: Dordrecht, the Netherlands, Springer, p. 57-90.

Xiao, S., Droser, M., Gehling, J.G., Hughes, I.V., Wan, B., Chen, Z., and Yuan, X., 2013, Affirming life aquatic for the Ediacara biota in China and Australia: Geology, v. 41, p. 1095-1098.

Xiao, S., Grazhdankin, D.V., Sovetov, J.K., Kaufman, A.J., and Rich, P., 2011, International Conference on Neoproterozoic Sedimentary Basins, Neoproterozoic Subcommission Workshop on Ediacaran Paleobiology, and IGCP Field Excursion to the East Sayan Mountain Range: Episodes, v. 34 , p. $273-275$.

Xiao, S., and Laflamme, M., 2009, On the eve of animal radiation: Phylogeny, ecology and evolution of the Ediacara biota: Trends in Ecology \& Evolution, v. 24, p. 31-40.

Xiao, S., McFadden, K.A., Peek, S., Kaufman, A.J., Zhou, C., Jiang, G., and $\mathrm{Hu}$, J., 2012, Integrated chemostratigraphy of the Doushantuo Formation at the northern Xiaofenghe section (Yangtze Gorges, South China) and its implication for Ediacaran stratigraphic correlation and ocean redox models: Precambrian Research, v. 192-195, p. 125-141.

Xiao, S., and Sharma, M., 2014, International Field Workshop on the Marwar Supergroup, Rajasthan, India: Episodes, v. 37, p. 74-75.

Xiao, S., Yuan, X., Steiner, M., and Knoll, A.H., 2002, Macroscopic carbonaceous compressions in a terminal Proterozoic shale: A systematic reassessment of the Miaohe biota, South China: Journal of Paleontology, v. 76, p. $347-376$

Xiao, S., Zhou, C., Liu, P., Wang, D., and Yuan, X., 2014a, Phosphatized acanthomorphic acritarchs and related microfossils from the Ediacaran Doushantuo Formation at Weng' an (South China) and their implications for biostratigraphic correlation: Journal of Paleontology, v. 88, p. 1-67.

Xiao, S., Zhou, C., and Zhu, M., 2014b, International symposium and field workshop on Ediacaran and Cryogenian stratigraphy: Episodes, v. 37, p. 218-221.

Yang, B., Steiner, M., Zhu, M., Li, G., Liu, J., and Liu, P., 2016, Transitional Ediacaran-Cambrian small skeletal fossil assemblages from South China and Kazakhstan: Implications for chronostratigraphy and metazoan evolution: Precambrian Research, v. 285, p. 202-215.

Ye, Q., Tong, J., Xiao, S., Zhu, S., An, Z., Tian, L., and Hu, J., 2015, The survival of benthic macroscopic phototrophs on a Neoproterozoic snowball Earth: Geology, v. 43, p. 507-510.

Yuan, X.L., Chen, Z., Xiao, S.H., Zhou, C.M., and Hua, H., 2011, An early Ediacaran assemblage of macroscopic and morphologically differentiated eukaryotes: Nature, v. 470, p. 390-393.

Zhang, Y., Yin, L., Xiao, S., and Knoll, A.H., 1998, Permineralized fossils from the terminal Proterozoic Doushantuo Formation, South China: Journal of Paleontology, v. 72 (supplement to No. 4), p. 1-52.

Zhao, Z., Xing, Y., Ding, Q., Liu, G., Zhao, Y., Zhang, S., Meng, X., Yin, C., Ning, B., and Han, P., 1988, The Sinian System of Hubei, Wuhan, China University of Geosciences Press, 205 p.

Zhou, C., and Xiao, S., 2007, Ediacaran $\delta^{13} \mathrm{C}$ chemostratigraphy of South China: Chemical Geology, v. 237, p. 89-108.

Zhou, C., Xie, G., McFadden, K., Xiao, S., and Yuan, X., 2007, The diversification and extinction of Doushantuo-Pertatataka acritarchs in South China: Causes and biostratigraphic significance: Geological Journal, v. 42, p. 229-262.

Zhu, B., Becker, H., Jiang, S.-Y., Pi, D.-H., Fischer-Gödde, M., and Yang, J.H., 2013a, Re-Os geochronology of black shales from the Neoproterozoic Doushantuo Formation, Yangtze platform, South China: Precambrian Research, v. 225, p. 67-76.

Zhou, C., Xiao, S., Wang, W., Guan, C., Ouyang, Q., and Chen, Z., in press, The stratigraphic complexity of the middle Ediacaran carbon isotopic record in the Yangtze Gorges area, South China, and its implications for the age and chemostratigraphic significance of the Shuram excursion: Precambrian Research.

Zhu, M., Gehling, J.G., Xiao, S., Zhao, Y.-L., and Droser, M., 2008, Eightarmed Ediacara fossil preserved in contrasting taphonomic windows from China and Australia: Geology, v. 36, p. 867-870.

Zhu, M., Lu, M., Zhang, J., Zhao, F., Li, G., Yang, A., Zhao, X., and Zhao, M., 2013b, Carbon isotope chemostratigraphy and sedimentary facies evolution of the Ediacaran Doushantuo Formation in western Hubei, South China: Precambrian Research, v. 225, p. 7-28.

Zhuravlev, A., Yu., Gámez Vintaned, J.A., and Ivantsov, A.Y., 2009, First finds of problematic Ediacaran fossil Gaojiashania in Siberia and its origin: Geological Magazine, v. 146, p. 775-780.

Zhuravlev, A., Yu., Liñán, E., Vintaned, J.A.G., Debrenne, F., and Fedorov, A.B., 2012, New finds of skeletal fossils in the terminal Neoproterozoic of the Siberian Platform and Spain: Acta Palaeontologica Polonica, v. 57 , p. $205-224$. 